\title{
The Outstanding Applications of Skeletal Numbers to Chemical Clusters
}

\author{
Enos Masheija Rwantale Kiremire
}

Correspondence: Enos Masheija Rwantale Kiremire, Department of Chemistry and Biochemistry, University of Namibia, Private Bag 13301, Windhoek, Namibia. E-mail: kiremire15@yahoo.com

Received: April 17, 2017 Accepted: May 11, 2017 Online Published: June 1, 2017

doi:10.5539/ijc.v9n3p28 URL: https://doi.org/10.5539/ijc.v9n3p28

\begin{abstract}
The evolution of the use of the $14 / 4 \mathrm{n}$ series method has resulted in the discovery of skeletal numbers. The skeletal numbers have rendered the testing of the 18 -and 8 -electron rules much easier and faster. In the same way, they have been very useful in simplifying the categorization of clusters, the prediction of shapes, and the matching of isolobal fragments. Furthermore, the skeletal numbers have made it possible to tentatively assign ligands to individual skeletal elements in such way that the 18- or 8-electron rule is obeyed. Thus, skeletal numbers can be utilized as a simple guide in analyzing and understanding clusters.
\end{abstract}

Keywords: clusters, $14 \mathrm{n} / 4 \mathrm{n}$ series, $18 / 8$-electron-rule, isolobal, fragment, skeletal, categorization

\section{Introduction}

The Wade-Mingos rules (PSEPT) have been exceedingly helpful in analyzing and categorizing clusters for several decades (Wade, 1971; Mingos, 1972; Rudolph, 1976; Welch, 2013). In an attempt to understand these rules and the pattern within clusters especially the osmium carbonyls, the $14 \mathrm{n}$ and $4 \mathrm{n}$ rules were revealed for transition and main group elements (Kiremire, 2014; Kiremire, 2015a). On further scrutiny of the series and clusters, the skeletal numbers of transition and main group elements were recently discovered (Kiremire, 2016a). These skeletal numbers have made the analysis and characterization of clusters much easier (Kiremire, 2016b). The aim of this paper is to point out some of the applications to chemical clusters that have so far been found by the use of skeletal numbers. It is hoped that our readers will enjoy the rapidity and smooth flow of using skeletal numbers to analyze and study clusters and that they can be applied to other more complex cluster systems.

\section{Results and Discussion}

The 4n(14n) series method developed in this work, in which $n$ represents the number of skeletal elements in a cluster, can be used to categorize a wide range of clusters, among others, transition metal carbonyls, boranes, heteroboranes, metalloboranes, Zintl ions, and gold clusters (Kiremire, 2015a, 2015b,2016c,2016d, 2017). Using the series formula, the number of valence electrons of a given cluster can easily be calculated directly without counting the valence electrons of individual skeletal atoms and ligands. Furthermore, from the series formula a corresponding required cluster formula can also be derived. For instance, for the series $S=4 n+2$ and $n=6$, a corresponding borane cluster can be illustrated by the formula $\mathrm{F}_{\mathrm{B}}=[\mathrm{BH}](6)+2 \mathrm{H}=\mathrm{B}_{6} \mathrm{H}_{8}=\mathrm{B}_{6} \mathrm{H}_{6}{ }^{2-}$, while a for Zintl ion cluster, $\mathrm{F}_{\mathrm{Z}}=[\mathrm{Pb}](6)+2-=\mathrm{Pb}_{6}{ }^{2-}$. However, for a corresponding transition metal carbonyl, say that of rhodium, $\mathrm{F}_{\mathrm{R}}=14 \mathrm{n}+2=\left[\mathrm{Rh}(\mathrm{H})(\mathrm{CO})_{2}\right](6)+\mathrm{CO}=\mathrm{Rh}_{6}(\mathrm{H})_{6}(\mathrm{CO})_{12}+\mathrm{CO}$ $=\mathrm{Rh}_{6}(\mathrm{CO})_{3}(\mathrm{CO})_{12}+\mathrm{CO}=\mathrm{Rh}_{6}(\mathrm{CO})_{16}$. On the other hand, a corresponding osmium cluster will be given by $\mathrm{F}_{\mathrm{O}}=$ $\left[\mathrm{Os}(\mathrm{CO})_{3}\right](6)+\mathrm{CO}=\mathrm{Os}_{6}(\mathrm{CO})_{19}=\mathrm{Os}_{6}(\mathrm{CO})_{18}{ }^{2-}$. For all these clusters, the building block for transition metals is based on a cluster fragment of [14] electrons, and for main group elements it is [4] electrons.

In order to easily follow the applications of skeletal numbers ( $\mathrm{K}$ values) in the areas to be briefly discussed, it is proposed that the assigned skeletal numbers (skeletal linkage values) of elements be provided for ease of reference, despite the fact that they have already appeared in print (Kiremire, 2016a). The $\mathrm{K}$ values are given in Tables 1 and 2. They are derived from applying the series formula to valence electrons of the elements (Kiremire, 2016a). The numbers are positive for main group and transition metal elements. Also, from the study of series, the ligands were also given $\mathrm{K}$ values. This assignment is also based on the knowledge of the same series. It was found that for every one electron donated by a ligand, $\mathrm{K}=-0.5$. Selected $\mathrm{K}$ values for ligands are given in Table 3 .

\subsection{Calculation of the K Value of a Cluster or Fragment}

This is simply done by adding up the respective skeletal numbers (obtained from Tables 1,2 and 3) of the skeletal elements and the ligands in a given chemical formula. Examples: 


$$
\begin{array}{ll}
\text { i. } & \mathrm{C}_{2}, \mathrm{~K}=2[2]=4 \\
\text { ii. } & \mathrm{BN}, \mathrm{K}=1[2.5]+1[1.5]=4 \\
\text { iii. } & \mathrm{CB}^{-}, \mathrm{K}=1[2]+1[2.5]+1(-0.5)=4 \\
\text { iv. } & \mathrm{CN}^{+}, \mathrm{K}=1[2]+1[1.5]+1(0.5)=4 \text {; }
\end{array}
$$

All the above chemical species are expected to possess quadruple bonds, demonstrated as sketch $\mathrm{S}-1 \mathrm{~A}$, where $\mathrm{E}$ is a skeletal atom.

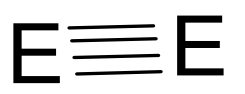

S-1A. The quadruple bond between two skeletal elements

This method can be used to calculate $\mathrm{K}$ values in other fragments or molecules.

v. $\mathrm{C}_{2} \mathrm{H}_{2}, \mathrm{~K}=2[2]+2(-0.5)=3$ (triple bond)

vi. $\mathrm{C}_{2} \mathrm{H}_{4}, \mathrm{~K}=2[2]+4(-0.5)=2$ (double bond)

vii. $\mathrm{C}_{2} \mathrm{H}_{6}, \mathrm{~K}=2[2]+6(-0.5)=1$ (single bond)
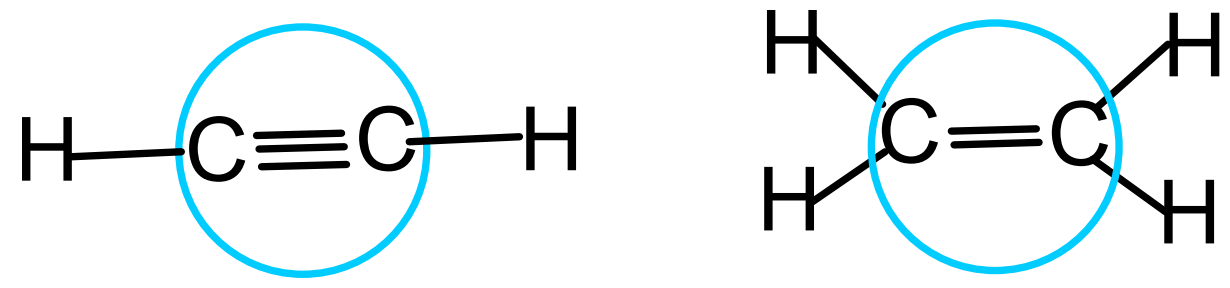

$$
K=3
$$$$
\mathrm{K}=2
$$

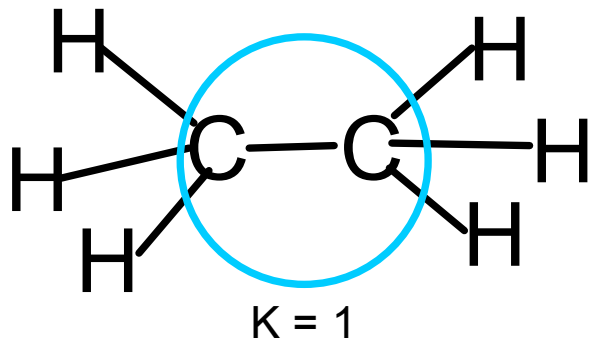

$\mathrm{S}-1 \mathrm{~B}$. The triple, double and single bonds derived from $\mathrm{C}_{2}$.

The presence of a quadruple bond in $\mathrm{C}_{2}$ sketched in S-1 A is still shrouded in controversy (de Sausa, et al, 2016). However, according to the $4 \mathrm{n}$ series method, the derived molecules from $\mathrm{C}_{2}$ such as $\mathrm{C}_{2} \mathrm{H}_{2}, \mathrm{C}_{2} \mathrm{H}_{4}$ and $\mathrm{C}_{2} \mathrm{H}_{6}$ are well known and possess triple, double and single bonds respectively as sketched in S-1B. This implies that the existence of a quadruple bond in $\mathrm{C}_{2}$ in support of the recent discovery (Shaik, S., et al, 2012) makes sense.

Table 1. Skeletal Numbers of Transition Metal Elements

\begin{tabular}{lllll}
\hline Element & Representative Group & Valence electrons & Series, $\mathrm{S}=14 \mathrm{n}+\mathrm{q}(\mathrm{n}=1)$ & $\mathrm{K}$ value=2n-q/2 \\
\hline $\mathrm{Sc}, \mathrm{Y}, \mathrm{La}$ & 3 & 3 & $14 \mathrm{n}-11$ & 7.5 \\
$\mathrm{Ti}, \mathrm{Zr}, \mathrm{Hf}$ & 4 & 4 & $14 \mathrm{n}-10$ & 7.0 \\
$\mathrm{~V}, \mathrm{Nb}, \mathrm{Ta}$ & 5 & 5 & $14 \mathrm{n}-9$ & 6.5 \\
$\mathrm{Cr}, \mathrm{Mo}, \mathrm{W}$ & 6 & 6 & $14 \mathrm{n}-8$ & 6.0 \\
$\mathrm{Mn}, \mathrm{Tc}, \mathrm{Re}$ & 7 & 7 & $14 \mathrm{n}-7$ & 5.5 \\
$\mathrm{Fe}, \mathrm{Ru}, \mathrm{Os}$ & 8 & 8 & $14 \mathrm{n}-6$ & 5.0 \\
$\mathrm{Co}, \mathrm{Rh}, \mathrm{Ir}$ & 9 & 9 & $14 \mathrm{n}-5$ & 4.5 \\
$\mathrm{Ni}, \mathrm{Pd}, \mathrm{Pt}$ & 10 & 10 & $14 \mathrm{n}-4$ & 4.0 \\
$\mathrm{Cu}, \mathrm{Ag}, \mathrm{Au}$ & 11 & 11 & $14 \mathrm{n}-3$ & 3.5 \\
$\mathrm{Zn}, \mathrm{Cd}, \mathrm{Hg}$ & 12 & 12 & $14 \mathrm{n}-2$ & 3.0 \\
\hline
\end{tabular}


Table 2. Skeletal Numbers of Main Group Elements

\begin{tabular}{lllll}
\hline Element & Representative Group & Valence electrons & Series, S = 4n+q(n=1) & K value =2n-q/2 \\
\hline $\mathrm{Li}, \mathrm{Na}, \mathrm{K}, \mathrm{Rb}, \mathrm{Cs}$ & 1 & 1 & $4 \mathrm{n}-3$ & 3.5 \\
$\mathrm{Be}, \mathrm{Mg}, \mathrm{Ca}, \mathrm{Sr}, \mathrm{Ba}$ & 2 & 2 & $4 \mathrm{n}-2$ & 3.0 \\
$\mathrm{~B}, \mathrm{Al}, \mathrm{Ga}, \mathrm{In}, \mathrm{Tl}$ & 3 & 3 & $4 \mathrm{n}-1$ & 2.5 \\
$\mathrm{C}, \mathrm{Si}, \mathrm{Ge}, \mathrm{Sn}, \mathrm{Pb}$ & 4 & 4 & $4 \mathrm{n}+0$ & 2.0 \\
$\mathrm{~N}, \mathrm{P}, \mathrm{As}, \mathrm{Sb}, \mathrm{Bi}$ & 5 & 5 & $4 \mathrm{n}+1$ & 1.5 \\
$\mathrm{O}, \mathrm{S}, \mathrm{Se}, \mathrm{Te}$ & 6 & 6 & $4 \mathrm{n}+2$ & 1.0 \\
$\mathrm{~F}, \mathrm{Cl}, \mathrm{Br}, \mathrm{I}$ & 7 & 7 & $4 \mathrm{n}+3$ & 0.5 \\
$\mathrm{Ne}, \mathrm{Ar}, \mathrm{Kr}, \mathrm{Xe}$ & 8 & 8 & $4 \mathrm{n}+4$ & 0.0 \\
\hline
\end{tabular}

The $K$ value is defined as $K=2 n-1 / 2 q$ where $q$ is a variable of the series $S=4 n+q$ for main group elements or $14 n+q$ for transition elements.

Table 3. Skeletal Numbers of Selected Ligands

\begin{tabular}{lll}
\hline NUMBER OF ELECTRONS DONATED BY LIGAND & K VALUE & EXAMPLES(NEUTRAL) \\
\hline 1 & -0.5 & $\mathrm{H}, \mathrm{X}=\mathrm{F}, \mathrm{Cl}, \mathrm{Br}, \mathrm{I}, \mathrm{R}($ alkyl, aryl) \\
2 & -1 & $\mathrm{CO}, \mathrm{PPh}_{3}, \mathrm{~N}_{2}, \mathrm{C}_{2} \mathrm{H}_{4}, \mathrm{NH}_{3}, \mathrm{H}_{2} \mathrm{O}$ \\
3 & -1.5 & $\eta^{3}-\mathrm{C}_{3} \mathrm{H}_{5}, \mathrm{NO}, \mathrm{CR}$ \\
4 & -2 & $\eta^{4}-\mathrm{C}_{4} \mathrm{H}_{4}$ \\
5 & -2.5 & $\eta^{5}-\mathrm{C}_{5} \mathrm{H}_{5}$ \\
6 & -3 & $\eta^{6}-\mathrm{C}_{6} \mathrm{H}_{6}$ \\
\hline
\end{tabular}

\subsection{Effect on the $K$ Value by Adding an Electron to or Removing an Electron from a Fragment}

In order to shed more light on the effect of adding an electron to or removing an electron from a fragment, some brief explanation is necessary. In this regard, Scheme 1 has been developed as an illustration. According to the series method, a set of four [4] electrons forms the basis of the $4 \mathrm{n}$ series approach. In this regard, suitable candidates for the $4 \mathrm{n}$ series are carbon [C] and [BH] skeletal fragments. The development of the $4 \mathrm{n}$ series was discussed amply in previous work (Kiremire, 2015a). For the purposes of this paper, a brief of outline of the method will be given below in order for the readers to appreciate the applications of the skeletal numbers explained in this paper. Let us consider a carbon skeletal element, [C]. The carbon atom has 4 valence electrons. This means it belongs to the series $S=4 n+0=V$ (valence electrons). For $\mathrm{n}=1, \mathrm{~S}=\mathrm{V}=4(1)+0=4$. The $\mathrm{K}$ value is defined as $\mathrm{K}=2 \mathrm{n}-1 / 2 \mathrm{q}$ where $\mathrm{q}$ is a variable of the series $\mathrm{S}=$ $4 n+q$ for main group elements or $14 n+q$ for transition elements. For the carbon skeletal element with $S=4 n+0, K=2 n-$ $1 / 2 \mathrm{q}=2(1)-1 / 2(0)=2$. This is the value indicated in Table 2 for $\mathrm{C}$ element and its family members (congeners). Let us consider adding a hydrogen atom $[\mathrm{H}]$ as a 'ligand' to the carbon[C] atom to produce a fragment $[\mathrm{CH}]$, or a negative charge to produce $\left[\mathrm{C}^{-}\right]$fragment. In so doing, we will increase the valence electron environment of the carbon atom by 1 unit and hence $\mathrm{V}=\mathrm{S}=4 \mathrm{n}+1$. The corresponding $\mathrm{K}$ value will be given by $\mathrm{K}=2 \mathrm{n}-1 / 2 \mathrm{q}=2(1)-1 / 2(1)=1.5$. In terms of valence electrons, the $[\mathrm{CH}]$ or $\left[\mathrm{C}^{-}\right]$fragment will correspond to the $[\mathrm{N}]$ skeletal element or any of the family members of group V elements. In other words, these are isolobal fragments, that is, $[\mathrm{CH}] \leftrightarrow\left[\mathrm{C}^{-}\right] \leftrightarrow[\mathrm{N}] \leftrightarrow[\mathrm{P}] \leftrightarrow[\mathrm{As}] \leftrightarrow[\mathrm{Sb}] \leftrightarrow[\mathrm{Bi}]$. Similarly, $\mathrm{CH}_{2} \leftrightarrow \mathrm{C}^{2-} \leftrightarrow \mathrm{O} \leftrightarrow \mathrm{S} \leftrightarrow \mathrm{Se} \leftrightarrow \mathrm{Te}$ with $\mathrm{S}=\mathrm{V}=4 \mathrm{n}+2=4(1)+2=6$ and $\mathrm{K}=2 \mathrm{n}-1 / 2 \mathrm{q}=2(1)-1 / 2(2)=1$ as given in Table 2. It is not difficult to see that with $\mathrm{CH}_{3} \leftrightarrow \mathrm{C}^{3-} \leftrightarrow \mathrm{F} \leftrightarrow \mathrm{Cl} \leftrightarrow \mathrm{Br} \leftrightarrow \mathrm{I}, \mathrm{S}=4 \mathrm{n}+3$, and $\mathrm{K}=0.5$. Let us start from a $\mathrm{C}$ skeletal element as a $4 \mathrm{n}$ series reference and move to the left in the second period of the periodic table by removing one electron from the carbon $[\mathrm{C}]$ atom. Then we will get a $\left[\mathrm{C}^{+}\right]$fragment. This fragment has 3 valence electrons and corresponds to a boron [B] skeletal element. Also the corresponding series will be given by $S=4 n-1=V=4(1)-1=3$. The $\mathrm{K}$ value for the series will be $\mathrm{K}=2 \mathrm{n}-1 / 2 \mathrm{q}=2(1)-1 / 2(-1)=2.5$. This corresponds to the $\mathrm{K}$ value of boron as shown in Table 2. Clearly going from $[\mathrm{C}]$ to $\left[\mathrm{C}^{+}\right]$, the $\mathrm{K}$ value increases from 2 to 2.5 by 0.5 . Similarly, for [C] to become $\left[\mathrm{C}^{2+}\right]$ $\left\{[\mathrm{C}] \rightarrow\left[\mathrm{C}^{2+}\right]\right\}, \mathrm{K}$ goes from 2.0 to 3.0 , so the increase is 1.0 . On the other hand for $[\mathrm{C}] \rightarrow\left[\mathrm{C}^{-}\right]$, $\mathrm{K}$ goes from 2.0 to 1.5 and thus there is a decrease of 0.5 . For $[\mathrm{C}] \rightarrow\left[\mathrm{C}^{2-}\right]$, the decrease will be 1.0. Some of the isolobal fragments corresponding to $\mathrm{C}^{+}$are $\mathrm{B}, \mathrm{Al}, \mathrm{Ga}$, $\mathrm{In}$, and $\mathrm{Tl}$, while those of $\mathrm{C}^{2+}$ are $\mathrm{Be}, \mathrm{Mg}, \mathrm{Ca}, \mathrm{Sr}$ and $\mathrm{Ba}$. The isolobal relationship is illustrated in Scheme 1.

\begin{tabular}{|c|c|c|c|c|c|c|c|c|}
\hline$S=4 n+q$ & $4 n-3$ & $4 n-2$ & $4 n-1$ & $4 n+0$ & $4 n+1$ & $4 n+2$ & $4 n+3$ & $4 n+4$ \\
\hline & & & & $\mathrm{C}$ & $\mathrm{C}^{-}$ & $\mathrm{C}^{2}-$ & $\mathrm{C}^{3}-$ & $\mathrm{C}^{4}-$ \\
\hline & $\mathrm{C}^{3+}$ & $\frac{\mathrm{C}^{2+}}{}$ & $L^{+}$ & $E$ & $\mathrm{CH}$ & $\mathrm{CH}_{2}$ & $\mathrm{CH}_{3}$ & $\mathrm{CH}_{4}$ \\
\hline & $\mathrm{Li}$ & $\mathrm{Be}$ & $\mathrm{B}$ & $\bar{C}$ & $\mathrm{~N}$ & $\mathrm{O}$ & $\mathrm{F}$ & $\overline{\mathrm{Ne}}$ \\
\hline V & 1 & 2 & 3 & 4 & 5 & 6 & 7 & 8 \\
\hline$K=2 n-1 / 2 q$ & 3.5 & 3.0 & 2.5 & 2.0 & 1.5 & 1.0 & 0.5 & 0.0 \\
\hline
\end{tabular}

$\mathrm{K}=$ Skeletal number, $\mathrm{V}=$ valence electrons, $\mathrm{S}=$ Series

Scheme 1. Influence on $\mathrm{K}$ value of adding or removing an electron from a fragment

We can also illustrate the significance of the skeletal numbers by calculating the $\mathrm{K}$ values of a few clusters. Consider $\mathrm{B}_{6} \mathrm{H}_{6}{ }^{2-}$ cluster: using the knowledge of skeletal numbers, its $\mathrm{K}$ value is given by $\mathrm{K}=6[2.5]+6[-0.5]+2[-0.5]=15-3-1$ 
$=11$. Similarly, for $\mathrm{Rh}_{6}(\mathrm{CO})_{16}, \mathrm{~K}=6[4.5]+16[-1]=27-16=11$. Also, for $\mathrm{Os}_{6}(\mathrm{CO})_{18}{ }^{2-}, \mathrm{K}=6[5]+18[-1]+2[-0.5]=$ $30-18-1=11$. This implies that the skeletal structures of $\mathrm{B}_{6} \mathrm{H}_{6}{ }^{2-}, \mathrm{Rh}_{6}(\mathrm{CO})_{16}$, and $\mathrm{Os}_{6}(\mathrm{CO})_{18}{ }^{2-}$ are similar or identical. In actual fact, all the above clusters have an octahedral geometry $\left(\mathrm{O}_{\mathrm{h}}\right)$. Let us consider a few more clusters. First, $\mathrm{Bi}_{5}{ }^{3+}$, $K=5[1.5]+3[0.5]=9 ; K(n)=9(5)$. Since $K=2 n-1 / 2 q$, then $q=2[2 n-K], q=2[2(5)-9]=2$ and $S=4 n+q=4 n+2$ (closo series). Similarly, for $\mathrm{Sn}_{5}{ }^{2-}, \mathrm{K}=5[2]+2[-0.5]=9 ; \mathrm{K}(\mathrm{n})=9(5)$, and $\mathrm{S}=4 \mathrm{n}+2$ (closo series). Another good example is $\mathrm{Os}_{5}(\mathrm{CO})_{15}{ }^{2-}$, for which $\mathrm{K}=5[5]+15[-1]+2[-0.5]=25-15-1=9 ; \mathrm{K}(\mathrm{n})=9(5)$, and $\mathrm{S}=4 \mathrm{n}+2$ (closo series). This means that we expect the clusters, $\mathrm{Bi}_{5}{ }^{3+}, \mathrm{Sn}_{5}{ }^{2-}$ and $\mathrm{Os}_{5}(\mathrm{CO})_{15}{ }^{2-}$ to have similar skeletal geometry. All these clusters have a trigonal bipyramid shape as predicted (King and Schleyer, 2004; Teo, et al, 1984). Furthermore, according to the series method in terms of ligand electron donation to skeletal elements, $\mathrm{H} \bullet \equiv 1 \mathrm{e} \equiv-1$ charge, for which the $\mathrm{K}$ value is -0.5 . $\mathrm{A}: \mathrm{CO}$ ligand may be regarded as equivalent to a -2 charge or ligand( $: \mathrm{L})$, for which $\mathrm{K}=-1$; For cyclopentadienyl ligand, $\mathrm{C}_{5} \mathrm{H}_{5}$ with five electron donation $5 \mathrm{e}, \mathrm{K}=-2.5$. One positive charge $(+1)$ corresponding to the removal of one electron, results in the increase of $\mathrm{K}$ value by 0.5 . This is similar to removing an electron from carbon in Scheme 1 above, so $\mathrm{C}$ $(\mathrm{K}=2.0)$ becomes $\mathrm{C}^{+}(\mathrm{K}=2.5)$, an increase $\Delta \mathrm{K}=0.5$. A charge of two units $(+2)$ on a skeletal system corresponds to an increase in $\mathrm{K}$ value by +1 , similar to $\mathrm{C}$ losing two electrons to become $\mathrm{C}^{2+}$ in Scheme 1. Likewise, $\mathrm{N}(\mathrm{K}=1.5)+\mathrm{O}(\mathrm{K}$ $=1.0) \rightarrow \mathrm{NO}(\mathrm{K}=2.5)$; also $\mathrm{NO}(\mathrm{K}=2.5)$ becomes $\mathrm{NO}^{+}(\mathrm{K}=2.5+0.5=3.0)$ by losing an electron, and $\mathrm{NO}(\mathrm{K}=2.5)+1 \mathrm{e}$ $\rightarrow \mathrm{NO}^{-}(\mathrm{K}=2.5-0.5=2.0)$. These simple results correspond to what is derived from the molecular orbital energy level diagrams of diatomic species (Cotton and Wilkinson, 1980; Meissler, Fischer and Tarr, 2014). The skeletal elements have positive $\mathrm{K}$ values. As indicated in Tables 1 and 2, the $\mathrm{K}$ values depend upon the valence electrons of the skeletal elements. The standard is four valence electrons [4] for the main group elements and [14] for the transition metal atoms.

\subsection{The Test for the 18- and 8-Electron Rules}

The 18 and 8 electron rules have been used in chemistry since the beginning of the $20^{\text {th }}$ century (Langmuir, 1921; Lewis, 1916). As we are aware, the 18-electron rule involves adding up the number of the electrons in the d atomic orbitals of the central metal atom and those donated by the ligands. If the counting gives 18 , then the complex obeys the 18 -electron rule. In the same manner, in the case of main group elements, if the addition gives 8 , then the molecule or ion obeys the 8-electron rule.

\subsubsection{Using Skeletal Numbers to Test The 18-Electron Rule}

The groups of transition elements were assigned positive skeletal numbers using series (Kiremire, 2016b). In addition, ligands were also assigned negative skeletal numbers based upon series. For a ligand that donates one electron such as a hydrogen atom, $\mathrm{H} \bullet, \mathrm{K}=-0.5$, while a for a carbonyl ligand that donates 2 electrons, : $\mathrm{CO}$ is assigned $\mathrm{K}=-1$. The skeletal element provides the skeletal linkages which get reduced when ligands are added to it. The ligand $\mathrm{K}$ value depends upon the number of electrons donated. The method of calculating the $\mathrm{K}$ value for a given cluster using skeletal numbers is straight- forward, and worked out examples are given in Table 4 below. Nonetheless, it is important to clarify the meaning of $\mathrm{K}$ values and how they are obtained, in the same table. Consider the cluster, $\mathrm{Fe}(\mathrm{CO})_{5}$ : the $\mathrm{K}$ value of iron $(\mathrm{Fe})$ is 5 as shown in Table 4 . If we carefully reflect, the $\mathrm{K}=5$ for Fe represents 8 valence electrons as obtained from the formula $\mathrm{S}=14 \mathrm{n}-6$ (where $\mathrm{n}=1$ ) and $\mathrm{K}=2 \mathrm{n}-1 / 2 \mathrm{q}=2(1)-1 / 2(-6)=5$. So if we add a :CO ligand we get a fragment $[\mathrm{Fe}(\mathrm{CO})]$, and the series becomes, $\mathrm{S}=14 \mathrm{n}-6+2=14 \mathrm{n}-4(\mathrm{n}=1)=14(1)-4=10$ and $\mathrm{K}=2 \mathrm{n}-1 / 2 \mathrm{q}=2(1)-1 / 2(-4)=4$. This is the same as adding $8+2=10$ for the $[\mathrm{Fe}(\mathrm{CO})]$ fragment. If we continue adding : $\mathrm{CO}$ ligands to the $\mathrm{Fe}$ skeletal atom to finally get a $\mathrm{Fe}(\mathrm{CO})_{5}$ fragment, the series becomes $\mathrm{S}=14 \mathrm{n}+4$ (where $\mathrm{n}=1$ ), so $\mathrm{S}=18$ which is the same as $\mathrm{V}$ ( total valence electrons). However the $K$ value will be given by $K=2 n-1 / 2 q=2(1)-1 / 2(+4)=0$. Thus, the 18 -electron rule is obeyed for a mono-skeletal cluster when $\mathrm{K}=\mathbf{0}$. This value is the same as calculated from the formula $\mathrm{Fe}(\mathrm{CO})_{5}, \mathrm{~K}=$ $1[5]+5[-1]=0$ using $\mathrm{K}=5$ for $\mathrm{Fe}$ and $\mathrm{K}=-1$ for the :CO ligand. This means the $\mathrm{K}=5$ takes into account the valence electrons for the Fe skeletal element and $\mathrm{K}=-5$ for the $5 \mathrm{CO}$ ligands takes into account the 10 electrons donated by the $5 \mathrm{CO}$ ligands. Therefore the overall $\mathrm{K}=0$ value embodies the 18 gross valence electrons of $\mathrm{Fe}$ and those donated by the 5 CO ligands. If one gets familiar with the use of skeletal numbers, it will be discerned that the calculations are much simpler and easier than the electron counting based upon using the valence electrons of the skeletal elements and ligands. Let us consider one more example: Does the complex, $\mathrm{Mo}(\mathrm{CO})_{4}{ }^{4-}$ obey the 18 -electron rule? We then perform a simple calculation: $\mathrm{K}=1[6]+4[-1]+4[-0.5]=6-4-2=0$. This means the complex obeys the 18 -electron rule. More mono-skeletal cluster examples are given in Table 4. 
Table 4. Skeletal Numbers of Selected Mono-skeletal Clusters

\begin{tabular}{|c|c|c|c|c|c|}
\hline CLUSTER & CALCULATION OF K VALUE & n VALUE & $\mathrm{K}(\mathrm{n})$ & SERIES & VALENCE ELECTRONS \\
\hline $\mathrm{Ni}(\mathrm{CO})_{4}$ & $1[4]-4=0$ & 1 & $0(1)$ & $4 n+4$ & $14(1)+4=18$ \\
\hline $\mathrm{Fe}(\mathrm{CO})_{5}$ & $1[5]-5=0$ & 1 & $0(1)$ & $4 n+4$ & $14(1)+4=18$ \\
\hline $\mathrm{Cr}(\mathrm{CO})_{6}$ & $1[6]-6=0$ & 1 & $0(1)$ & $4 n+4$ & $14(1)+4=18$ \\
\hline$\left.\eta^{6}-\mathrm{C}_{6} \mathrm{H}_{6} \mathrm{CrCO}\right)_{3}$ & $1[6]-3-3=0$ & 1 & $0(1)$ & $4 n+4$ & $14(1)+4=18$ \\
\hline $\mathrm{H}_{2} \mathrm{Fe}(\mathrm{CO})_{4}$ & $1[5]-1-4=0$ & 1 & $0(1)$ & $4 n+4$ & $14(1)+4=18$ \\
\hline $\mathrm{CpFe}(\mathrm{CO})_{2}^{-}$ & $1[5]-2.5-2-0.5=0$ & 1 & $0(1)$ & $4 n+4$ & $14(1)+4=18$ \\
\hline $\mathrm{Fe}(\mathrm{CO})_{4}{ }^{2 / 2}$ & $1[5]-4-1=0$ & 1 & $0(1)$ & $4 n+4$ & $14(1)+4=18$ \\
\hline $\mathrm{Mo}(\mathrm{CO})_{4}{ }^{4}$ & $1[6]-4-2=0$ & 1 & $0(1)$ & $4 n+4$ & $14(1)+4=18$ \\
\hline $\mathrm{HFe}(\mathrm{CO})_{4}^{-}$ & $1[5]-4-0.5-0.5=0$ & 1 & $0(1)$ & $4 n+4$ & $14(1)+4=18$ \\
\hline $\mathrm{HMn}(\mathrm{CO})_{5}$ & $1[5.5]-0.5-5=0$ & 1 & $0(1)$ & $4 n+4$ & $14(1)+4=18$ \\
\hline$\left(\eta^{6}-\mathrm{C}_{6} \mathrm{H}_{6}\right)_{2} \mathrm{Cr}$ & $1[6]-2(3)=0$ & 1 & $0(1)$ & $4 n+4$ & $14(1)+4=18$ \\
\hline$\left(\eta^{7}-\mathrm{C}_{7} \mathrm{H}_{7}\right) \mathrm{Mo}(\mathrm{CO})_{3}{ }^{+}$ & $1[6]-3.5-3+0.5=0$ & 1 & $0(1)$ & $4 n+4$ & $14(1)+4=18$ \\
\hline$\left(\eta^{4}-\mathrm{C}_{4} \mathrm{H}_{4}\right) \mathrm{Fe}(\mathrm{CO})_{3}$ & $1[5]-2-3=0$ & 1 & $0(1)$ & $4 n+4$ & $14(1)+4=18$ \\
\hline $\mathrm{CpFe}(\mathrm{CO})_{2} \mathrm{Cl}$ & $1[5]-2.5-2-0.5=0$ & 1 & $0(1)$ & $4 n+4$ & $14(1)+4=18$ \\
\hline $\mathrm{Mn}(\mathrm{CO})_{5} \mathrm{Cl}$ & $1[5.5]-5-0.5=0$ & 1 & $0(1)$ & $4 n+4$ & $14(1)+4=18$ \\
\hline$(\mathrm{Cp})_{2} \mathrm{Fe}$ & $1[5]-2(2.5)=0$ & 1 & $0(1)$ & $4 n+4$ & $14(1)+4=18$ \\
\hline $\mathrm{Ti}(\mathrm{CO})_{6}{ }^{2}-$ & $1[7]-6-1=0$ & 1 & $0(1)$ & $4 n+4$ & $14(1)+4=18$ \\
\hline$(\mathrm{Cp})_{2} \mathrm{Co}^{+}$ & $1[4.5]-2(2.5)+0.5=0$ & 1 & $0(1)$ & $4 n+4$ & $14(1)+4=18$ \\
\hline$\left(\eta^{5}-\mathrm{C}_{5} \mathrm{H}_{5}\right)\left(\eta^{3}-\mathrm{C}_{5} \mathrm{H}_{5}\right) \mathrm{Fe}(\mathrm{CO})$ & $1[5]-2.5-1.5-1=0$ & 1 & $0(1)$ & $4 n+4$ & $14(1)+4=18$ \\
\hline $\mathrm{V}(\mathrm{CO})_{6}^{-}$ & $1[6.5]-6-0.5=0$ & 1 & $0(1)$ & $4 n+4$ & $14(1)+4=18$ \\
\hline $\mathrm{Ti}(\mathrm{CO})_{6}^{2-}$ & $1[7]-6-1=0$ & 1 & $0(1)$ & $4 n+4$ & $14(1)+4=18$ \\
\hline $\mathrm{Mn}(\mathrm{CO})_{6}^{+}$ & $1[5.5]-6+0.5=0$ & 1 & $0(1)$ & $4 n+4$ & $14(1)+4=18$ \\
\hline $\mathrm{Fe}(\mathrm{CO})_{6}{ }^{2+}$ & $1[5]-6+1=0$ & 1 & $0(1)$ & $4 n+4$ & $14(1)+4=18$ \\
\hline $\mathrm{Co}(\mathrm{CO})_{4}^{-}$ & $1[4.5]-4-0.5=0$ & 1 & $0(1)$ & $4 n+4$ & $14(1)+4=18$ \\
\hline (Cp)Ni(NO) & $1[4]-2.5-1.5=0$ & 1 & $0(1)$ & $4 n+4$ & $14(1)+4=18$ \\
\hline $\mathrm{HCo}(\mathrm{CO})_{4}$ & $1[4.5]-0.5-4=0$ & 1 & $0(1)$ & $4 n+4$ & $14(1)+4=18$ \\
\hline $\mathrm{ReH}_{9}^{2-}$ & $1[5.5]-4.5-1=0$ & 1 & $0(1)$ & $4 n+4$ & $14(1)+4=18$ \\
\hline $\mathrm{FeH}_{6}^{4-}$ & $1[5]-3-2=0$ & 1 & $0(1)$ & $4 n+4$ & $14(1)+4=18$ \\
\hline $\mathrm{NiH}_{4}^{4-}$ & $1[4]-2-2=0$ & 1 & $0(1)$ & $4 n+4$ & $14(1)+4=18$ \\
\hline $\mathrm{CuH}_{4}{ }^{3-}$ & $1[3.5]-2-1.5=0$ & 1 & $0(1)$ & $4 n+4$ & $14(1)+4=18$ \\
\hline $\mathrm{RhClL}_{3}, \mathrm{~L}=\mathrm{PPh}_{3}$ & $1[4.5]-0.5-3=1$ & 1 & $1(1)$ & $4 n+2$ & $14(1)+2=16$ \\
\hline $\mathrm{Rh}(\mathrm{CO})_{2} \mathrm{I}_{2}^{-}$ & $1[4.5]-2-1-0.5=1$ & 1 & $1(1)$ & $4 n+2$ & $14(1)+2=16$ \\
\hline $\mathrm{HCo}(\mathrm{CO})_{4}$ & $1[4.5]-0.5-4=0$ & 1 & $0(1)$ & $4 n+4$ & $14(1)+4=18$ \\
\hline $\mathrm{HRh}(\mathrm{CO})_{4}$ & $1[4.5]-0.5-4=0$ & 1 & $0(1)$ & $4 n+4$ & $14(1)+4=18$ \\
\hline $\mathrm{HRh}(\mathrm{CO}) \mathrm{L}_{3}$ & $1[4.5]-0.5-1-3=0$ & 1 & $0(1)$ & $4 n+4$ & $14(1)+4=18$ \\
\hline $\mathrm{Ru}(\mathrm{CO})_{2} \mathrm{I}_{3}-$ & $1[5]-2-1.5-0.5=1$ & 1 & $1(1)$ & $4 n+2$ & $14(1)+2=16$ \\
\hline$(\mathrm{Cp})_{2} \mathrm{TiMe}_{2}$ & $1[7]-2(2.5)-1=1$ & 1 & $1(1)$ & $4 n+2$ & $14(1)+2=16$ \\
\hline (Cp) ${ }_{2} \mathrm{ZrH}_{2}$ & $1[7]-5-1=1$ & 1 & $1(1)$ & $4 n+2$ & $14(1)+2=16$ \\
\hline
\end{tabular}

2.3.2 Using Skeletal Numbers to Test the 8-Electron Rule

The procedure used for main group elements is the same as in the case of transition metals. The worked out examples are given in Table 5. The 8-electron rule is obeyed when $\mathrm{K}=0$ for a mono-skeletal cluster.

Table 5. Skeletal Numbers of Selected Mono-skeletal Main group Elements

\begin{tabular}{llllll}
\hline FRAGMENT/MOLECULE & K VALUE & n VALUE & K(n) & SERIES & VALENCE ELECTRONS \\
$\mathrm{H}_{2} \mathrm{O}$ & $1[1]-2(0.5)=0$ & 1 & $0(1)$ & $4 \mathrm{n}+4$ & $4(1)+4=8$ \\
$\mathrm{NH}_{4}{ }^{+}$ & $1[1.5]-4(0.5)+0.5=0$ & 1 & $0(1)$ & $4 \mathrm{n}+4$ & $4(1)+4=8$ \\
$\mathrm{CH}_{4}$ & $1[2]-4(0.5)=0$ & 1 & $0(1)$ & $4 \mathrm{n}+4$ & $4(1)+4=8$ \\
$\mathrm{NH}_{3}-$ & $1[1.5]-3(0.5)=0$ & 1 & $0(1)$ & $4 \mathrm{n}+4$ & $4(1)+4=8$ \\
$\mathrm{NH}_{2}^{-}$ & $1[1.5]-2(0.5)-0.5=0$ & 1 & $0(1)$ & $4 \mathrm{n}+4$ & $4(1)+4=8$ \\
$\mathrm{HCl}^{-}$ & $1[0.5]-0.5=0$ & 1 & $0(1)$ & $4 \mathrm{n}+4$ & $4(1)+4=8$ \\
$\mathrm{Cl}^{-}$ & $1[0.5]-0.5=0$ & 1 & $0(1)$ & $4 \mathrm{n}+4$ & $4(1)+4=8$ \\
$\mathrm{O}^{2-}$ & $1[1]-1=0$ & 1 & $0(1)$ & $4 \mathrm{n}+4$ & $4(1)+4=8$ \\
$\mathrm{~N}^{3-}$ & $1[1.5]-1.5=0$ & 1 & $0(1)$ & $4 \mathrm{n}+4$ & $4(1)+4=8$ \\
$\mathrm{OH}^{-}$ & $1[1]-1(0.5)-0.5=0$ & 1 & $0(1)$ & $4 \mathrm{n}+4$ & $4(1)+4=8$ \\
\hline
\end{tabular}

\subsection{USING Skeletal Numbers to Categorize and Predict Shapes for Clusters}

\subsubsection{Categorization of Clusters}

The use of skeletal numbers to categorize clusters has been done (Kiremire, 2017). This is yet another area where skeletal numbers are extremely useful. Nonetheless, let us take a few more examples for illustrations.

Let us consider the nickel complex, $\mathrm{Ni}_{5}(\mathrm{CO})_{12}{ }^{2-}$. From Table 1, nickel skeletal element was assigned a $\mathrm{K}$ value of 4 according to the series method, and for each : $\mathrm{CO}$ ligand, $\mathrm{K}=-1$ for the donation of two electrons to the skeletal element. The negative charge of two (-2) of the complex, also has a $\mathrm{K}$ value -1 just like each of the CO ligands. Hence the $\mathrm{K}$ 
value of the cluster, will be given by $K=5[4]+12[-1]+2[-0.5]=20-12-1=7$. The $\mathrm{K}$ value of the cluster is given by $\mathrm{K}$ $=2 \mathrm{n}-1 / 2 \mathrm{q}$, and $\mathrm{n}=5$. Therefore, $7=2(5)-1 / 2 \mathrm{q}$, and $1 / 2 \mathrm{q}=10-7=3$ and hence $\mathrm{q}=6$. The $\mathrm{Ni}_{5}(\mathrm{CO})_{12}{ }^{2-}$ cluster belongs to the series, $S=4 n+6$. The $K$ values can be calculated in the same way and series determined. The similar clusters are given in examples 1 to 7 . The clusters with $K=7$ and $n=5$ are expressed as $K(n)=7(5)$ and their shapes have been described as elongated trigonal bipyramid while those with $\mathrm{K}(\mathrm{n})=9(5)$ have been described as regular trigonal bipyramid (Teo, et al, 1984).

$$
\begin{array}{ll}
\text { 1. } & \mathrm{Ni}_{3} \mathrm{Cr}_{2}(\mathrm{CO})_{16}{ }^{2-} ; \mathrm{K}=3[4]+2[6]-16-1=7, \mathrm{~K}(\mathrm{n})=7(5) \rightarrow \mathrm{S}=4 \mathrm{n}+6 \\
\text { 2. } & \mathrm{RuIr}_{4}(\mathrm{CO})_{15}{ }^{2-} ; \mathrm{K}=1[5]+4[4.5]-15-1=7, \mathrm{~K}(\mathrm{n})=7(5) \rightarrow \mathrm{S}=4 \mathrm{n}+6 \\
\text { 3. } & \mathrm{PtRh}_{4}(\mathrm{CO})_{14}{ }^{2-} ; \mathrm{K}=1[4]+4[4.5]-14-1=7, \mathrm{~K}(\mathrm{n})=7(5) \rightarrow \mathrm{S}=4 \mathrm{n}+6 \\
\text { 4. } & \mathrm{B}_{5} \mathrm{H}_{11} ; \mathrm{K}=5[2.5]-5.5=7, \mathrm{~K}(\mathrm{n})=7(5) \rightarrow \mathrm{S}=4 \mathrm{n}+6
\end{array}
$$

The possible ideal shape of the above examples (1 to 4$)$ is shown as sketch S-2.

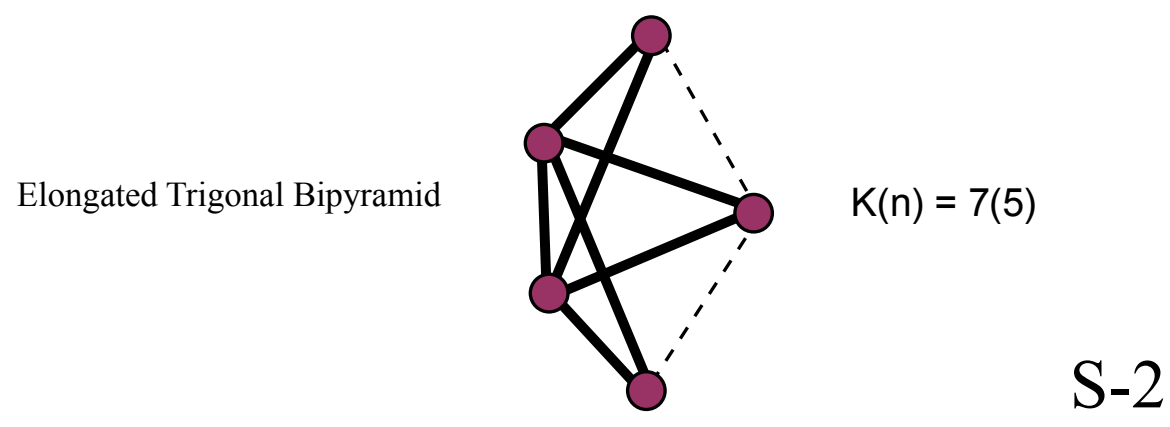

For the examples 5 to 7 below, the ideal shape is shown in sketch S-3.

5. $\mathrm{Os}_{5}(\mathrm{CO})_{16} ; \mathrm{K}=5[5]-16=9, \mathrm{~K}(\mathrm{n})=9(5) \rightarrow \mathrm{S}=4 \mathrm{n}+2$

6. $\mathrm{PtRh}_{4}(\mathrm{CO})_{12}{ }^{2-} ; \mathrm{K}=1[4]+4[4.5]-12-1=9, \mathrm{~K}(\mathrm{n})=9(5) \rightarrow \mathrm{S}=4 \mathrm{n}+2$

7. $\mathrm{B}_{5} \mathrm{H}_{5}{ }^{2-} ; \mathrm{K}=5[2.5]-2.5-1=9, \mathrm{~K}(\mathrm{n})=9(5) \rightarrow \mathrm{S}=4 \mathrm{n}+2$

Regular Trigonal Bipyramid

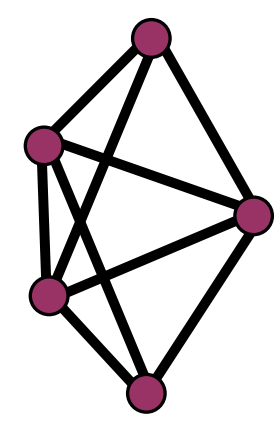

$\mathrm{K}(\mathrm{n})=9(5)$

\section{S-3}

8. $\mathrm{Ru}_{6}(\mathrm{~B})(\mathrm{CO})_{16}(\mathrm{AuL})_{3}$

The above is an example of a heterometal nanocluster (Ciabatti, 2015).

Using the skeletal numbers and the series, as simple as they look, we are able to predict the geometry of some clusters with seemingly formidable formulas. For instance, we know that $\mathrm{Ru}(\mathrm{K}=5), \mathrm{B}(\mathrm{K}=-1.5$ taken as a ligand $), \mathrm{CO}(\mathrm{K}=-1)$, $\mathrm{Au}(\mathrm{K}=3.5)$, and $\mathrm{L}(\mathrm{K}=-1)$. Hence the $\mathrm{K}$ value of the cluster is given by: $\mathrm{K}=6[5]+1[-1.5]+16[-1]+3[3.5-1]=20$. Since $\mathrm{n}=9(6 \mathrm{Ru}+3 \mathrm{Au})$, then we have the parameter $\mathrm{K}(\mathrm{n})=20(9)$. We can derive the cluster series from $\mathrm{K}(\mathrm{n})$ as follows: $K=2 n-1 / 2 q$ : $K=20=2(9)-1 / 2$ q; $1 / 2 q=18-20=-2$, and hence $\mathrm{q}=-4$. Therefore the $\mathrm{S}=4 \mathrm{n}+\mathrm{q}=4 \mathrm{n}-4 ; \mathrm{Cp}=$ $\mathrm{C}^{3} \mathrm{C}[\mathrm{M}-6]$.

\subsubsection{The Capping and Capping Symbol}

The symbol $\mathrm{Cp}=\mathrm{C}^{3} \mathrm{C}[\mathrm{M}-6]$ derived from the cluster series in example 8 was introduced in earlier work(Kiremire,2015d). Since many readers are not familiar with the Capping Symbol $(\mathrm{Cp})$ and its relationship with series, it is important to explain it briefly. Let us look at the following set of series: $S=4 n+10$ (Klado), $4 n+8$ (Hypho), $4 \mathrm{n}+6$ (Arachno), 4n+4(Nido), 4n+2(Closo), 4n+0(Mono-cap), 4n-2(Bi-cap), 4n-4(Tri-cap), 4n-6(Tetra-cap), 
4n-8(Penta-cap) and 4n-10(Hexa-cap); cap = capping. Boranes, heteroboranes, Zintyl ions and hydrocarbons normally belong to members of the series $4 \mathrm{n}+\mathrm{q}$ where $\mathrm{q}>0$. A large number of transition metal carbonyl clusters, metalloboranes and golden clusters belong to the series $S=4 \mathrm{n}+\mathrm{q}$, where $\mathrm{q} \leq 0$. This means that a good percentage of these clusters are highly capped (Kiremire, 2017). A series symbol for these was created, $S=4 n+q$ as well as its corresponding $K$ value given by $K=2 \mathrm{n}-1 / 2 \mathrm{q}$. Since all the clusters which belong to the series $\mathrm{S}=4 \mathrm{n}+\mathrm{q}(\mathrm{q} \leq 0)$ are capped, it was important to find a symbol for it. When we take a closer look at the sequence of the series $S=4 n+0$ (Mono-cap, $C^{1}$ ), $4 n-2\left(B i-c a p, C^{2}\right.$ ), $4 \mathrm{n}-4\left(\right.$ Tri-cap, $\left.\mathrm{C}^{3}\right)$, and $4 \mathrm{n}-6\left(\right.$ Tetra-cap, $\left.\mathrm{C}^{4}\right)$, etc a beautiful pattern emerges. Thus, for $\mathrm{q}=0$, we have a mono-capped cluster, $C^{1}, q=-2, C^{2}$, a bi-capped cluster, $q=-4, C^{3}$, a tri-capped cluster, and so on. A Capping Symbol, $C p=C^{n} C[M-x]$ where $\mathrm{n}$ is the number of skeletal atoms capping, $\mathrm{x}$ is the number of skeletal elements around which the capping takes place, and M stands for skeletal element, was introduced (Kiremire, 2015b, 2015d,2017). It is quite clear that the number of capping elements correspond to the multiple of $(-2)$ in the series. Hence, for the cluster $\mathrm{Ru}_{6}(\mathrm{~B})(\mathrm{CO})_{16}(\mathrm{AuL})_{3}$ the series is $S=4 n-4=4 n+2(-2)$. This could be translated as $4 n+0,1$ capping atom, and 2(-2) which represents 2 other capping elements. This gives a total of $1+2=3$ capping skeletal elements out of a total of 9 skeletal elements. The remaining 6 un-capped elements belong to the $S=4 n+2$ series and constitute an octahedral inner cluster nucleus. This is what is observed in sketch S-4, which has been previously identified (Ciabatti,2015). It is found that all the 3 gold skeletal elements are capping around the 6 nickel skeletal elements which constitute an octahedral geometry, $\mathrm{O}_{\mathrm{h}}$. What is interesting is that all the three gold skeletal atoms are capping around the octahedral ruthenium skeletal elements.

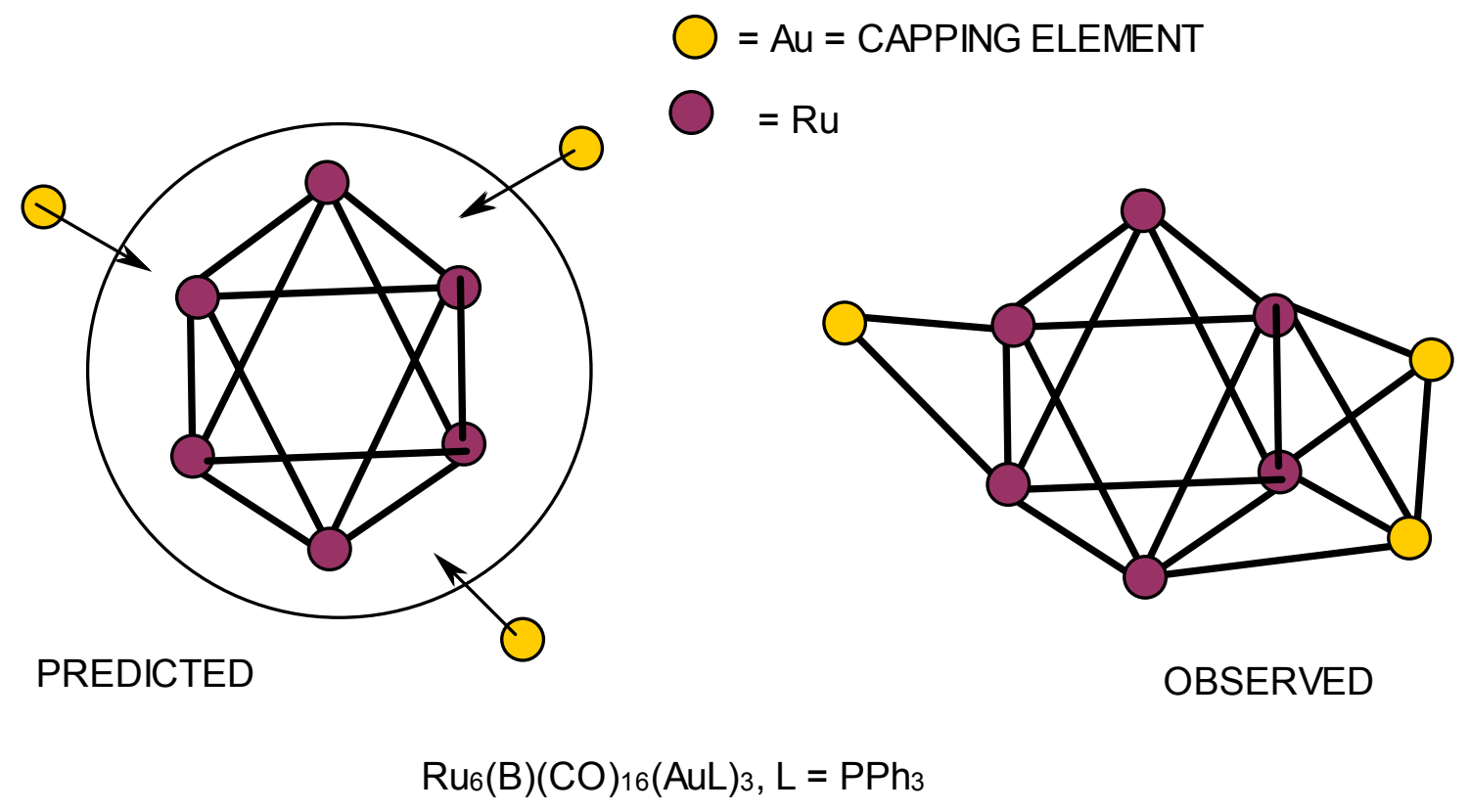


$K=2 n-1 / 2 q ; \quad q=2[2 n-K]$

$K(n), K=$ cluster number, $n=$ number of identified skeletal elements

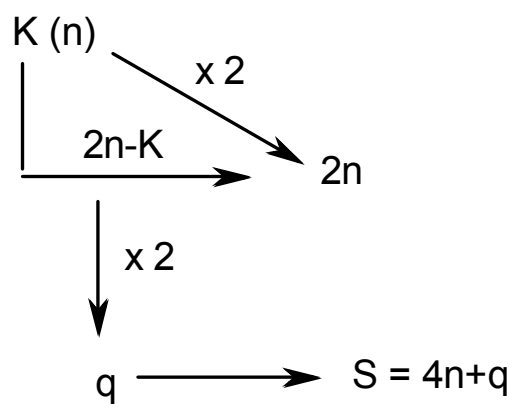

Scheme 2. Derivation of Series Formula from K(n) Parameter

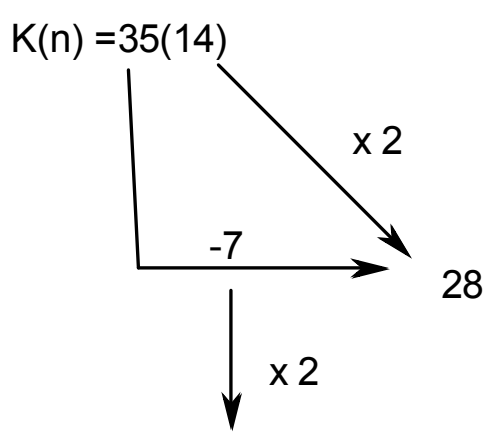

$-14 \longrightarrow \mathrm{S}=4 \mathrm{n}-14 ; \mathrm{Cp}=\mathrm{C}^{8} \mathrm{C}[\mathrm{M}-6]$

Scheme 3. Example illustrating the derivation of the Cluster Series Formula

From the capping symbol $\mathrm{Cp}=\mathrm{C}^{8} \mathrm{C}[\mathrm{M}-6]$, we know that the cluster has an octahedral nucleus capped by 8 skeletal elements. This is what is observed in sketch S-5 which was previously identified (Ciabatti, 2015). It is found that all the 8 gold skeletal elements are capping around the nickel skeletal elements which constitute an octahedral geometry, $\mathrm{O}_{\mathrm{h}}$. This is a clear testimony of the power of the series method for categorizing clusters. 


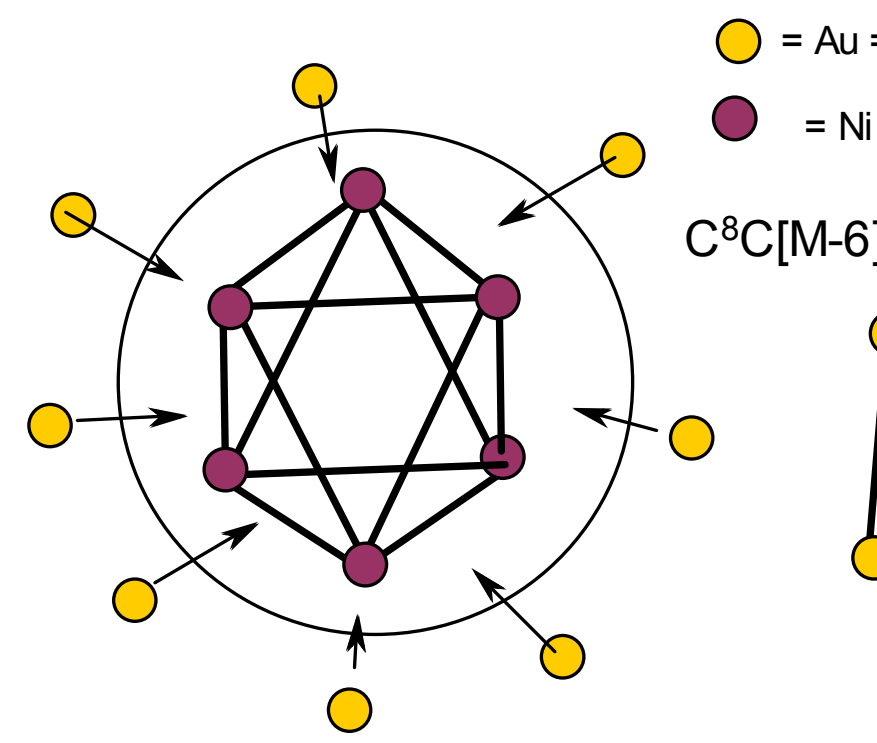

PREDICTED SKETCH

$$
\begin{gathered}
\mathrm{Ni6}(\mathrm{C})(\mathrm{CO})_{8}(\mathrm{AuL})_{8}{ }^{2+}, \quad L=\mathrm{PPh}_{3} \\
\text { S-5 }
\end{gathered}
$$


10. $\mathrm{Au}_{8} \mathrm{~L}^{2+}, \mathrm{L}=\mathrm{PPh}_{3}$

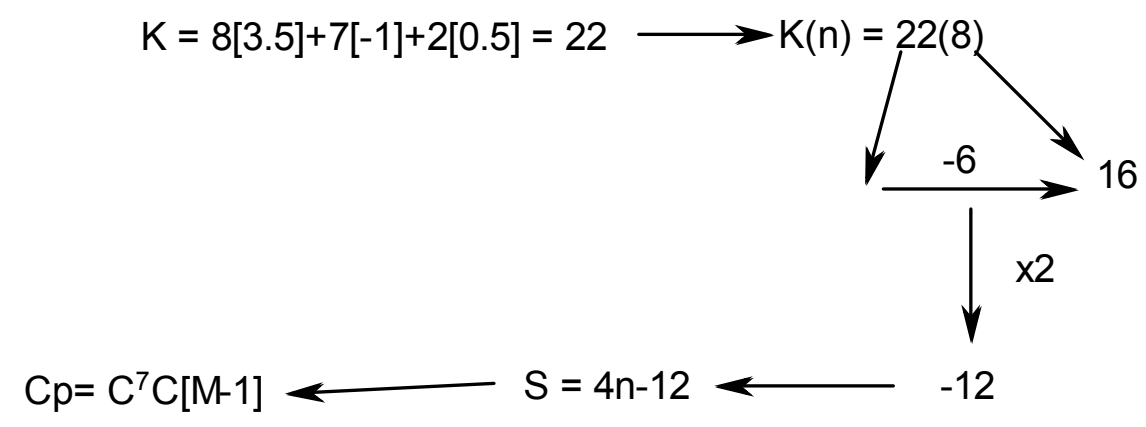

This implies that the golden cluster has ONE skeletal atom at the cluster nucleus with the rest of the skeletal elements surrounding it(capping). This is found to be the case. This is sketched in S-6.
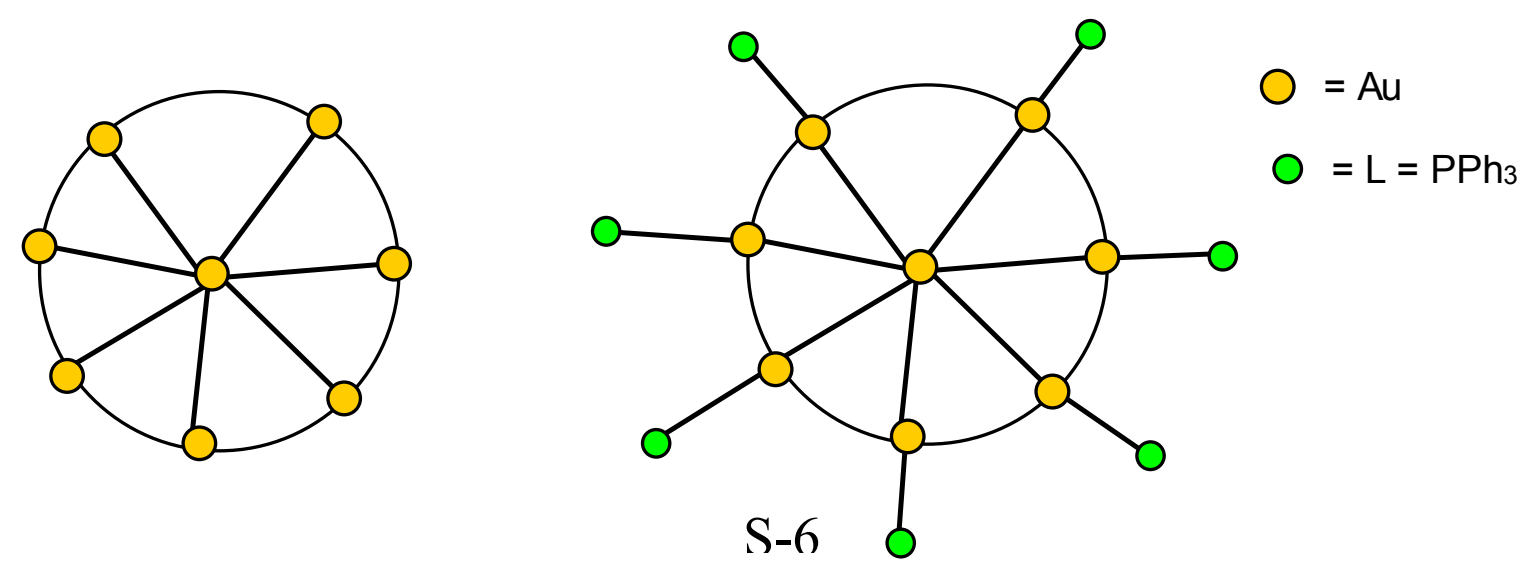

In this golden cluster, the 7 capping golden skeletal elements each possess a ligand while the one in the nucleus has no ligand. 


\section{1. $\mathrm{Pt}_{5}(\mathrm{CO})_{6} \mathrm{~L}_{4}$}

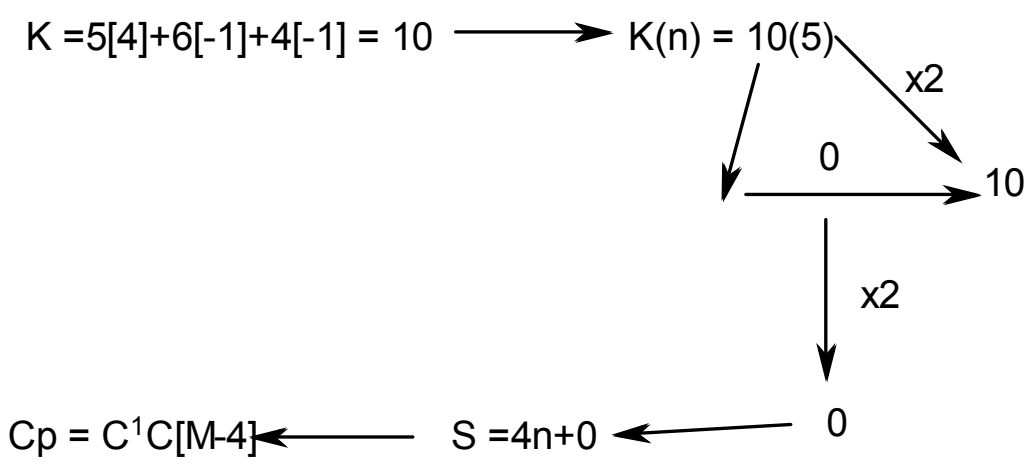

The capping symbol, $\mathrm{Cp}=\mathrm{C}^{1} \mathrm{C}[\mathrm{M}-4]$ means that the cluster comprized of 4 platinum skeletal elements which form a tetrahedral shape, $T_{d}$, while one of the five platinum skeletal element sits in a capping position.
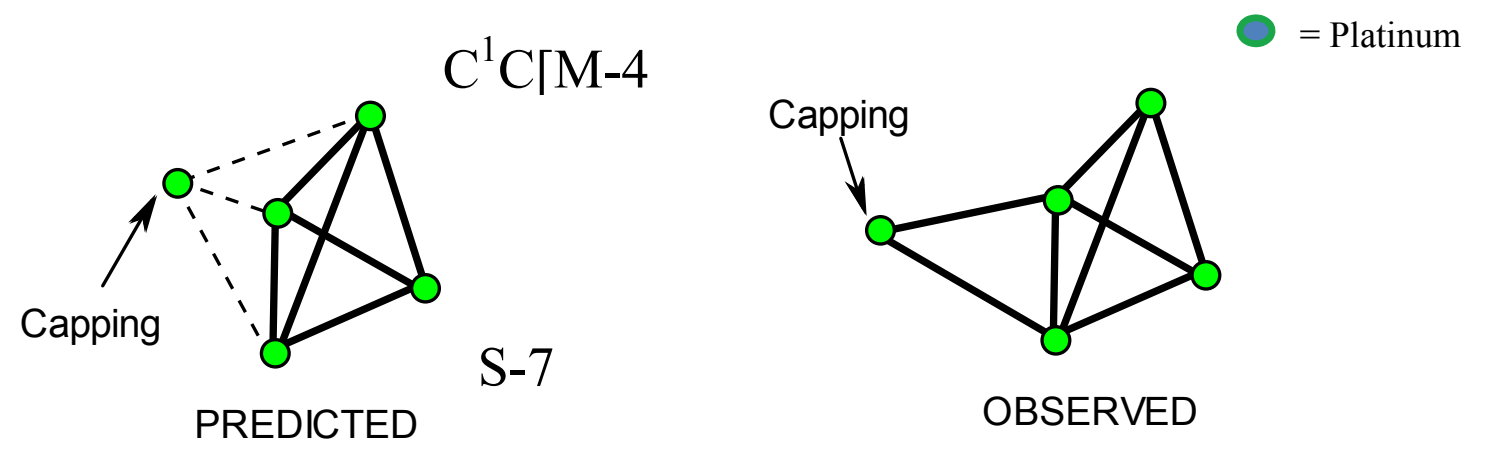

Sketch S-7 shows the predicated and observed geometry of the above cluster (Ciabatti, 2015). Not only is the $4 \mathrm{n}$ series method easy to work with, but is also quite precise in predicting the skeletal shape of a cluster.

More examples to demonstrate the power of skeletal numbers to categorize clusters are given in Table 6. 
Table 6. Examples of Categorized Clusters

\begin{tabular}{|c|c|c|c|c|c|c|}
\hline CLUSTER & $\begin{array}{lll}\text { CALCULATION } & \text { OF } & \mathrm{K} \\
\text { VALUE } & & \\
\end{array}$ & n VALUE & $\mathrm{K}(\mathrm{n})$ & SERIES & $\begin{array}{l}\text { VALENCE } \\
\text { ELECTRONS }\end{array}$ & CATEGORY \\
\hline $\mathrm{B}_{4} \mathrm{H}_{10}$ & $4[2.5]-5=5$ & 4 & $5(4)$ & $4 n+6$ & $4(4)+6=22$ & ARACHNO \\
\hline $\mathrm{Os}_{5}(\mathrm{CO})_{16}$ & $5[5]-16=9$ & 5 & $9(5)$ & $4 n+2$ & $14(5)+2=72$ & CLOSO \\
\hline $\mathrm{B}_{5} \mathrm{H}_{9}$ & $5[2.5]-4.5=8$ & 5 & $8(5)$ & $4 n+4$ & $4(5)+4=24$ & NIDO \\
\hline $\mathrm{B}_{4} \mathrm{H}_{8} \mathrm{Fe}(\mathrm{CO})_{3}$ & $4[2.5]+1[5]-4-3=8$ & 5 & $8(5)$ & $4 n+4$ & $4(5)+4+1(10)=34$ & NIDO \\
\hline $\mathrm{B}_{5} \mathrm{H}_{11}$ & $5[2.5]-5.5=7$ & 5 & $7(5)$ & $4 n+6$ & $4(5)+6=26$ & ARACHNO \\
\hline $\mathrm{Co}_{4} \mathrm{Ni}_{2}(\mathrm{CO})_{14}{ }^{2-}$ & $4[4.5]+2[4]-14-1=11$ & 6 & $11(6)$ & $4 n+2$ & $14(6)+2=86$ & CLOSO \\
\hline $\mathrm{B}_{6} \mathrm{H}_{10}$ & $6[2.5]-5=10$ & 6 & $10(6)$ & $4 n+4$ & $4(6)+4=28$ & NIDO \\
\hline $\mathrm{CB}_{5} \mathrm{H}_{9}$ & $1[2]+5[2.5]-4.5=10$ & 6 & $10(6)$ & $4 n+4$ & $4(6)+4=28$ & NIDO \\
\hline $\mathrm{B}_{7} \mathrm{H}_{7}{ }^{2-}$ & $7[2.5]-3.5-1=13$ & 7 & $13(7)$ & $4 n+2$ & $4(7)+2=30$ & CLOSO \\
\hline $\mathrm{C}_{2} \mathrm{~B}_{6} \mathrm{H}_{10}$ & $2[2]+6[2.5]-5=14$ & 8 & $14(8)$ & $4 n+4$ & $4(8)+4=36$ & NIDO \\
\hline $\mathrm{B}_{8} \mathrm{H}_{14}$ & $8[2.5]-7=13$ & 8 & $13(8)$ & $4 n+6$ & $4(8)+6=38$ & ARACHNO \\
\hline $\mathrm{Rh}_{9}(\mathrm{P})(\mathrm{CO})_{21}{ }^{2-}$ & $9[4.5]-2.5-21-1=16$ & 9 & $16(9)$ & $4 n+4$ & $14(9)+4=130$ & NIDO \\
\hline $\mathrm{B}_{9} \mathrm{H}_{15}$ & $9[2.5]-7.5=15$ & 9 & $15(9)$ & $4 n+6$ & $4(9)+6=42$ & ARACHNO \\
\hline $\mathrm{B}_{10} \mathrm{H}_{12}$ & $10[2.5]-6=19$ & 10 & $19(10)$ & $4 n+2$ & $4(10)+2=42$ & CLOSO \\
\hline $\mathrm{B}_{10} \mathrm{H}_{10}{ }^{6-}$ & $10[2.5]-5-3=17$ & 10 & $17(10)$ & $4 n+6$ & $4(10)+6=46$ & ARACHNO \\
\hline $\mathrm{B}_{10} \mathrm{H}_{15}-$ & $10[2.5]-7.5-0.5=17$ & 10 & $17(10)$ & $4 n+6$ & $4(10)+6=46$ & ARACHNO \\
\hline $\mathrm{B}_{10} \mathrm{H}_{14}$ & $10[2.5]-7=18$ & 10 & $18(10)$ & $4 n+4$ & $4(10)+4=44$ & NIDO \\
\hline $\mathrm{B}_{9} \mathrm{H}_{11} \mathrm{~S}$ & $9[2.5]+1[1]-5.5=18$ & 10 & $18(10)$ & $4 n+4$ & $4(10)+4=44$ & NIDO \\
\hline$(\mathrm{CpCo}) \mathrm{C}_{2} \mathrm{~B}_{7} \mathrm{H}_{11}$ & $1[4.5]+2[2]+7[2.5]-2.5-5.5=18$ & 10 & $18(10)$ & $4 n+4$ & $4(10)+4+1(10)=54$ & NIDO \\
\hline $\mathrm{C}_{2} \mathrm{~B}_{9} \mathrm{H}_{11}$ & $2[2]+9[2.5]-5.5=21$ & 11 & $21(11)$ & $4 n+2$ & $4(11)+2=46$ & CLOSO \\
\hline $\mathrm{B}_{11} \mathrm{H}_{11}^{4-}$ & $11[2.5]-5.5-2=20$ & 11 & $20(11)$ & $4 n+4$ & $4(11)+4=48$ & NIDO \\
\hline $\mathrm{B}_{11} \mathrm{H}_{13}{ }^{2-}$ & $11[2.5]-6.5-1=20$ & 11 & $20(11)$ & $4 n+4$ & $4(11)+4=48$ & NIDO \\
\hline $\mathrm{B}_{10} \mathrm{CPH}_{11}$ & $10[2.5]+1[2]+1[1.5]-5.5=23$ & 12 & $23(12)$ & $4 n+2$ & $4(12)+2=50$ & CLOSO \\
\hline $\mathrm{B}_{12} \mathrm{H}_{12}^{2-}$ & $12[2.5]-6-1=23$ & 12 & $23(12)$ & $4 n+2$ & $4(12)+2=50$ & CLOSO \\
\hline $\mathrm{Fe}_{5}(\mathrm{C})(\mathrm{CO})_{15}$ & $5[5]-2-15=8$ & 5 & $8(5)$ & $4 n+4$ & $14(5)+4=74$ & NIDO \\
\hline $\mathrm{Ru}_{6}(\mathrm{C})(\mathrm{CO})_{17}$ & $6[5]-2-17=11$ & 6 & $11(6)$ & $4 n+2$ & $14(6)+2=86$ & CLOSO \\
\hline $\mathrm{Co}_{4}(\mathrm{PPh})_{2}(\mathrm{CO})_{10}$ & $4[4.5]+2[1.5]-1-11=9$ & 6 & $9(6)$ & $4 n+6$ & $4(6)+6+4(10)=70$ & ARACHNO \\
\hline $\mathrm{Sn}_{9} \mathrm{Cr}(\mathrm{CO})_{3}$ & $9[2]+1[6]-3=21$ & 10 & $21(10)$ & $4 n-2$ & $4(10)-2+1(10)=48$ & $\mathrm{C}^{1} \mathrm{C}[\mathrm{M}-9]$ \\
\hline
\end{tabular}

2.5 Using Skeletal Numbers to identify a Selected Common Geometry Within Clusters

The examples below have been selected to demonstrate the method of calculating $\mathrm{K}(\mathrm{n})$ and the categorization of a cluster according to $4 \mathrm{n}$ Series. For the same examples, the linkage to symmetry is shown in sketch S-8. These are given in Table 7.

Table 7. Identification of Clusters with Ideal Tetrahedral Skeletal Shape Using K(n) Parameter

\begin{tabular}{llllll}
\hline CLUSTER & CALCULATION OF K VALUE & $n$ VALUE & $\mathrm{K}(\mathrm{n})$ & SERIES, S & VALENCE ELECTRONS \\
\hline $\mathrm{Os}_{4}(\mathrm{CO})_{14}$ & $4[5]-14=6$ & 4 & $6(4)$ & $4 \mathrm{n}+4$ & $14(4)+4=60$ \\
$\mathrm{P}_{4}$ & $4[1.5]=6$ & 4 & $6(4)$ & $4 \mathrm{n}+4$ & $4(4)+4=20$ \\
$\mathrm{Ir}_{4}(\mathrm{CO})_{12}$ & $4[4.5]-12=6$ & 4 & $6(4)$ & $4 \mathrm{n}+4$ & $14(4)+4=60$ \\
$\mathrm{Re}_{4} \mathrm{H}_{4}(\mathrm{CO})_{13}{ }^{2-}$ & $4[5.5]-2-13-1=6$ & 4 & $6(4)$ & $4 \mathrm{n}+4$ & $14(4)+4=60$ \\
$\mathrm{Rh}_{4}(\mathrm{CO})_{11}^{2-}$ & $4[4.5]-11-1=6$ & 4 & $6(4)$ & $4 \mathrm{n}+4$ & $14(4)+4=60$ \\
$\mathrm{~S}_{2} \mathrm{Fe}_{2}(\mathrm{CO})_{6}{ }^{2-}$ & $2[1]+2[5]-6=6$ & 4 & $6(4)$ & $4 \mathrm{n}+4$ & $4(4)+4+2(10)=40$ \\
$\mathrm{SeFe}_{3}(\mathrm{CO})_{9}{ }^{2-}$ & $1[1]+3[5]-9-1=6$ & 4 & $6(4)$ & $4 \mathrm{n}+4$ & $4(4)+4+3(10)=50$ \\
$\mathrm{Fe}_{4}(\mathrm{CO})_{4}(\mathrm{Cp})_{4}$ & $4[5]-4-4(2.5)=6$ & 4 & $6(4)$ & $4 \mathrm{n}+4$ & $14(4)+4=60$ \\
$\mathrm{InBi}_{3}{ }^{2-}$ & $1[2.5]+3[1.5]-1=6$ & 4 & $6(4)$ & $4 \mathrm{n}+4$ & $4(4)+4=20$ \\
$\mathrm{GaBi}_{3}{ }^{2-}$ & $1[2.5]+3[1.5]-1=6$ & 4 & $6(4)$ & $4 \mathrm{n}+4$ & $4(4)+4=20$ \\
$\mathrm{FeIr}_{3}(\mathrm{CO})_{12}{ }^{-}$ & $1[5]+3[4.5]-12-0.5=6$ & 4 & $6(4)$ & $4 \mathrm{n}+4$ & $14(4)+4=60$ \\
$\mathrm{Fe}_{2} \mathrm{Ir}_{2}(\mathrm{CO})_{12}{ }^{2-}$ & $2[5]+2[4.5]-12-1=6$ & 4 & $6(4)$ & $4 \mathrm{n}+4$ & $14(4)+4=60$ \\
\hline
\end{tabular}

The ideal shape corresponding to the parameter $\mathrm{K}(\mathrm{n})=6(4)$ is tetrahedral as shown in sketch S-8.

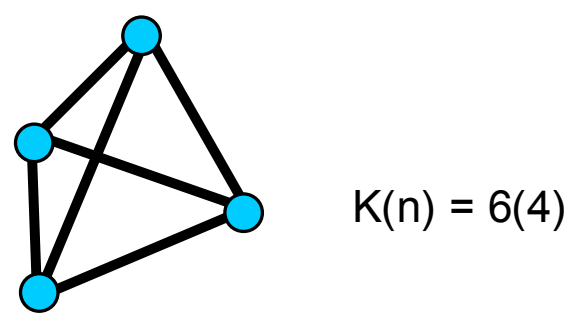

S-8

2.6 Using Skeletal Numbers to Match Isolobal Fragments

Isolobal fragments are extremely important in linking inorganic chemistry with organic chemistry (Hoffmann, 1982). 
Using skeletal numbers, isolobal fragments can easily be identified by calculating the $\mathrm{K}$ value of the fragments. Categorization of isolobal fragments using $14 \mathrm{n}$ and $4 \mathrm{n}$ series was done earlier (Kiremire, 2015c). The isolobal fragments with their corresponding $\mathrm{K}$ values are given in Table 8 . From this table, we can readily pick out the following selected isolobal relationships.

Table 8. Identification of Isolobal Fragments Using Skeletal Numbers

\begin{tabular}{|c|c|c|c|}
\hline FRAGMENT & CALCULATION OF K VALUE & $\mathrm{K}(\mathrm{n})$ & SERIES, $\mathrm{S}$ \\
\hline $\mathrm{CH}_{2}^{2-}$ & $1[2]-1-1=0$ & $0(1)$ & $4 n+4$ \\
\hline $\mathrm{CH}_{3}^{-}$ & $1[2]-1.5-0.5=0$ & $0(1)$ & $4 n+4$ \\
\hline $\mathrm{NH}_{2}^{-}$ & $1[1.5]-1-0.5=0$ & $0(1)$ & $4 n+4$ \\
\hline $\mathrm{CH}_{3}$ & $1[2]-1.5=0.5$ & $0.5(1)$ & $4 n+3$ \\
\hline $\mathrm{CH}_{2}^{-}$ & $1[2]-1-0.5=0.5$ & $0.5(1)$ & $4 n+3$ \\
\hline $\mathrm{Co}(\mathrm{CO})_{4}$ & $1[4.5]-4=0.5$ & $0.5(1)$ & $4 n+3$ \\
\hline $\mathrm{Mn}(\mathrm{CO})_{5}$ & $1[5.5]-5=0.5$ & $0.5(1)$ & $4 n+3$ \\
\hline $\mathrm{CpNi}(\mathrm{CO})$ & $1[4]-2.5-1=0.5$ & $0.5(1)$ & $4 n+3$ \\
\hline $\mathrm{Cu}(\mathrm{CO})_{3}$ & $1[3.5]-3=0.5$ & $0.5(1)$ & $4 n+3$ \\
\hline $\mathrm{F}$ & $1[0.5]=0.5$ & $0.5(1)$ & $4 n+3$ \\
\hline $\mathrm{MnL}_{5}$ & $1[5.5]-5=0.5$ & $0.5(1)$ & $4 n+3$ \\
\hline $\mathrm{CpFe}(\mathrm{CO})_{2}$ & $1[5]-2.5-2=0.5$ & $0.5(1)$ & $4 n+3$ \\
\hline $\mathrm{Fe}(\mathrm{CO})_{5}^{+}$ & $1[5]-5+0.5=0.5$ & $0.5(1)$ & $4 n+3$ \\
\hline $\mathrm{CpCr}(\mathrm{CO})_{3}$ & $1[6]-2.5-3=0.5$ & $0.5(1)$ & $4 n+3$ \\
\hline $\mathrm{AsMe}_{2}$ & $1[1.5]-1=0.5$ & $0.5(1)$ & $4 n+3$ \\
\hline $\mathrm{CH}_{3}^{+}$ & $1[2]-1.5+0.5=1$ & $1(1)$ & $4 n+2$ \\
\hline $\mathrm{Mn}(\mathrm{CO})_{5}^{+}$ & $1[5.5]-5+0.5=1$ & $1(1)$ & $4 n+2$ \\
\hline $\mathrm{CH}_{2}$ & $1[2]-1=1$ & $1(1)$ & $4 n+2$ \\
\hline $\mathrm{CR}_{2}$ & $1[2]-1=1$ & $1(1)$ & $4 n+2$ \\
\hline $\mathrm{SnR}_{2}$ & $1[2]-1=1$ & $1(1)$ & $4 n+2$ \\
\hline $\mathrm{Fe}(\mathrm{CO})_{4}$ & $1[5]-4=1$ & $1(1)$ & $4 n+2$ \\
\hline $\mathrm{Ru}(\mathrm{CO})_{4}$ & $1[5]-4=1$ & $1(1)$ & $4 n+2$ \\
\hline $\mathrm{Os}(\mathrm{CO})_{4}$ & $1[5]-4=1$ & $1(1)$ & $4 n+2$ \\
\hline $\mathrm{Cr}(\mathrm{CO})_{5}$ & $1[6]-5=1$ & $1(1)$ & $4 n+2$ \\
\hline $\mathrm{CpCo}(\mathrm{CO})$ & $1[4.5]-2.5-1=1$ & $1(1)$ & $4 n+2$ \\
\hline $\mathrm{CpMn}(\mathrm{CO})_{2}$ & $1[5.5]-2.5-2=1$ & $1(1)$ & $4 n+2$ \\
\hline $\mathrm{Re}(\mathrm{CO})_{4}{ }^{-}$ & $1[5.5]-4-0.5=1$ & $1(1)$ & $4 n+2$ \\
\hline $\mathrm{CpFe}(\mathrm{CO})^{-}$ & $1[5]-2.5-1-0.5=1$ & $1(1)$ & $4 n+2$ \\
\hline $\mathrm{CH}_{3}^{+}$ & $1[2]-1.5+0.5=1$ & $1(1)$ & $4 n+2$ \\
\hline $\mathrm{Cr}(\mathrm{CO})_{5}$ & $1[6]-5=1$ & $1(1)$ & $4 n+2$ \\
\hline $\mathrm{CH}$ & $1[2]-0.5=1.5$ & $1.5(1)$ & $4 n+1$ \\
\hline CR & $1[2]-0.5=1.5$ & $1.5(1)$ & $4 n+1$ \\
\hline $\mathrm{Co}(\mathrm{CO})_{3}$ & $1[4.5]-3=1.5$ & $1.5(1)$ & $4 n+1$ \\
\hline $\mathrm{Mn}(\mathrm{CO})_{4}$ & $1[5.5]-4=1.5$ & $1.5(1)$ & $4 n+1$ \\
\hline $\mathrm{CpNi}$ & $\mathrm{I}[4]-2.5=1.5$ & $1.5(1)$ & $4 n+1$ \\
\hline $\mathrm{CpFe}(\mathrm{CO})$ & $1[5]-2.5-1=1.5$ & $1.5(1)$ & $4 n+1$ \\
\hline $\mathrm{Rh}(\mathrm{CO})_{3}$ & $1[4.5]-3=1.5$ & $1.5(1)$ & $4 n+1$ \\
\hline $\operatorname{Ir}(\mathrm{CO})_{3}$ & $1[4.5]-3=1.5$ & $1.5(1)$ & $4 n+1$ \\
\hline $\mathrm{Fe}(\mathrm{H})(\mathrm{CO})_{3}$ & $1[5]-0.5-3=1.5$ & $1.5(1)$ & $4 n+1$ \\
\hline $\mathrm{CpW}(\mathrm{CO})_{2}$ & $1[6]-2.5-2=1.5$ & $1.5(1)$ & $4 n+1$ \\
\hline $\mathrm{CpCr}(\mathrm{CO})_{2}$ & $1[6]-2.5-2=1.5$ & $1.5(1)$ & $4 n+1$ \\
\hline $\mathrm{Cr}(\mathrm{CO})_{5}{ }^{+2}$ & $1[6]-5+0.5=1.5$ & $1.5(1)$ & $4 n+1$ \\
\hline $\mathrm{CH}_{2}^{+}$ & $1[2]-1+0.5=1.5$ & $1.5(1)$ & $4 n+1$ \\
\hline $\mathrm{P}^{2}$ & $1[1.5]=1.5$ & $1.5(1)$ & $4 n+1$ \\
\hline $\mathrm{BH}^{-}$ & $1[2.5]-0.5-0.5=1.5$ & $1.5(1)$ & $4 n+1$ \\
\hline $\mathrm{BH}$ & $1[2.5]-0.5=2$ & $2(1)$ & $4 n+0$ \\
\hline $\mathrm{CpFe}^{-}$ & $1[5]-2.5-0.5=2$ & $2(1)$ & $4 n+0$ \\
\hline $\mathrm{CpCo}$ & $1[4.5]-2.5=2$ & $2(1)$ & $4 n+0$ \\
\hline $\mathrm{C}$ & $1[2]=2$ & $2(1)$ & $4 n+0$ \\
\hline $\mathrm{CH}^{+}$ & $1[2]-0.5+0.5=2$ & $2(1)$ & $4 n+0$ \\
\hline $\mathrm{Fe}(\mathrm{CO})_{3}$ & $1[5]-3=2$ & $2(1)$ & $4 n+0$ \\
\hline $\mathrm{Cr}(\mathrm{CO})_{4}$ & $1[6]-4=2$ & $2(1)$ & $4 n+0$ \\
\hline $\mathrm{CpCo}$ & $1[4.5]-2.5=2$ & $2(1)$ & $4 n+0$ \\
\hline $\mathrm{CpMn}(\mathrm{CO})$ & $1[5.5]-2.5-1=2$ & $2(1)$ & $4 n+0$ \\
\hline
\end{tabular}

A simple illustration of the isolobal relationship of $\mathrm{P}, \mathrm{CH}$ and $\mathrm{Co}(\mathrm{CO})_{3}$ is given in sketch S-9. 


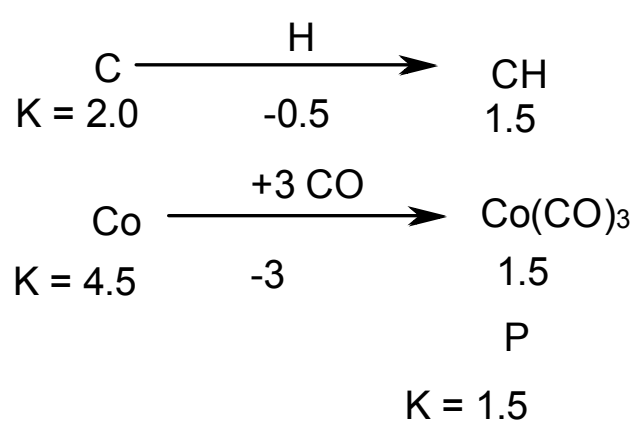

$\mathrm{P} \leftrightarrow \mathrm{CH} \leftrightarrow \mathrm{Co}(\mathrm{CO})_{3}$

Some more examples of isolobal relationships are given blow.

$$
\begin{aligned}
& \text { i. } \mathrm{CH}_{2}{ }^{2-} \leftrightarrow \mathrm{CH}_{3}-\leftrightarrow \mathrm{NH}_{2}{ }^{-}, \mathrm{K}=0 \\
& \text { ii. } \mathrm{CH}_{3} \leftrightarrow \mathrm{Mn}(\mathrm{CO})_{5} \leftrightarrow \mathrm{Co}(\mathrm{CO})_{4}{ }^{\leftrightarrow} \rightarrow(\mathrm{Cp}) \mathrm{Ni}(\mathrm{CO}), \mathrm{K}=0.5 \\
& \text { iii. } \mathrm{CH}_{2} \leftrightarrow \mathrm{Fe}(\mathrm{CO})_{4} \leftrightarrow \mathrm{Cr}(\mathrm{CO})_{5} \leftrightarrow \mathrm{O}, \mathrm{K}=1 \\
& \text { iv. } \mathrm{CH} \leftrightarrow \mathrm{CR} \leftrightarrow \mathrm{Co}(\mathrm{CO})_{3} \leftrightarrow \mathrm{Mn}(\mathrm{CO})_{4} \leftrightarrow(\mathrm{Cp}) \mathrm{Ni} \leftrightarrow \mathrm{P}, \mathrm{K}=1.5 \\
& \text { v. } \mathrm{C} \leftrightarrow \mathrm{Fe}(\mathrm{CO})_{3}{ }^{\leftrightarrow} \mathrm{Ru}(\mathrm{CO})_{3} \leftrightarrow \mathrm{Os}(\mathrm{CO})_{3} \leftrightarrow \mathrm{Cr}(\mathrm{CO})_{4} \leftrightarrow(\mathrm{Cp}) \mathrm{Co} \leftrightarrow(\mathrm{Cp}) \mathrm{Mn}(\mathrm{CO}), \mathrm{K}=2
\end{aligned}
$$

\subsection{Using Skeletal Numbers to Distribute Ligands onto Skeletal Elements in a Cluster}

The shapes of skeletal elements and the ligands distributed around them are very important. The x-ray crystal structure analysis has been crucial in providing such information (Cotton and Wilkinson, 1980; Greenwood and Earnshaw, 1998; Housecroft and Sharpe, 2005; Miessler, Fischer and Tarr, 2014).It has been found that the use of skeletal numbers helps immensely in distributing ligands around skeletal elements in such a way that the 18-or 8-electron rule is obeyed. In this way, hypothetical shapes of clusters can be obtained. The actual shapes can only be deduced from experimental determinations. The first step in distributing the ligands around skeletal elements is to determine the possible skeletal shape of the cluster from the cluster formula. The second one is to assign and determine the $\mathrm{K}$ value of each skeletal element in the assigned geometry using the skeletal numbers. Let us illustrate this by a few examples, starting with the cobalt complex in Figure (F-1).

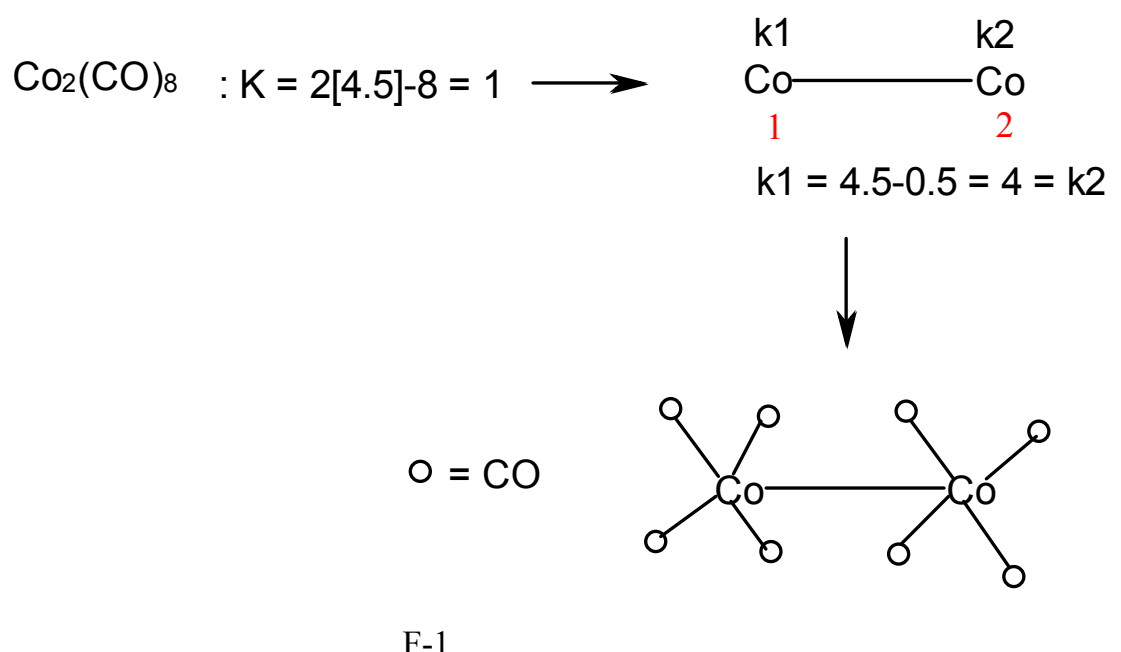

From Table 1 , the cobalt atom is assigned a $\mathrm{K}$ value of 5 . The above calculation shows that the complex, $\mathrm{Co}{ }_{2}(\mathrm{CO})_{8}$ has a $\mathrm{K}$ value of 1 . This means there is one Co-Co metal-metal bond. In this metal-metal bond, one of the electrons comes from cobalt 1 while the other comes from cobalt 2 . This concept is simply represented in diagram D-1. 


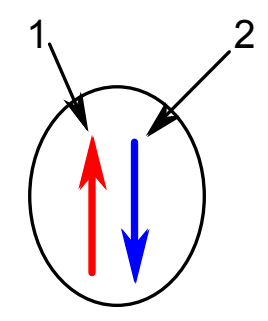

D-1

If we regard the electron from cobalt 2 as being donated to cobalt 1 like a one electron donor ligand, then $\mathrm{k} 1=4.5-0.5=$ 4.0. In order for cobalt 1 to obey the 18-electron rule, 4 carbonyl ligands must be added to cobalt 1 . Similarly, 4 other carbonyls must be added to cobalt 2 . This gives rise to figure F-1. The same explanations can be extended to figures F-2 to F-9.

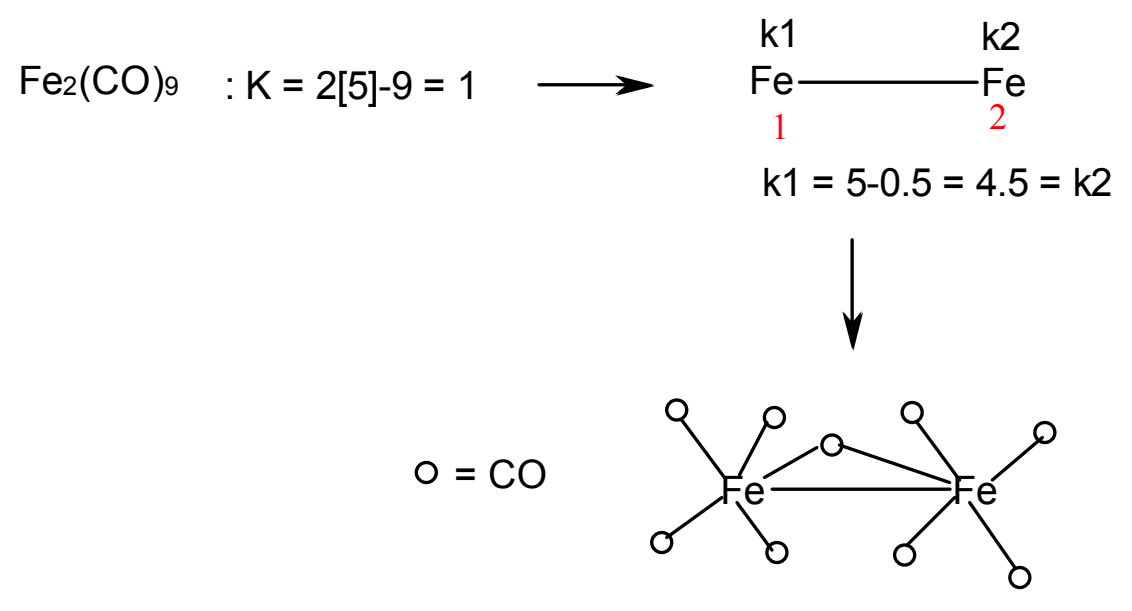

F-2

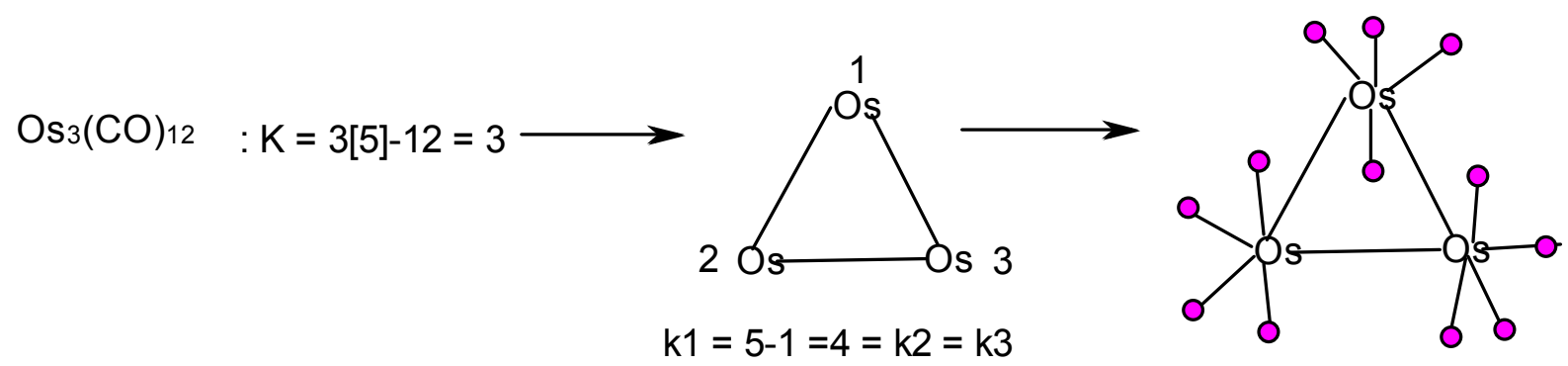




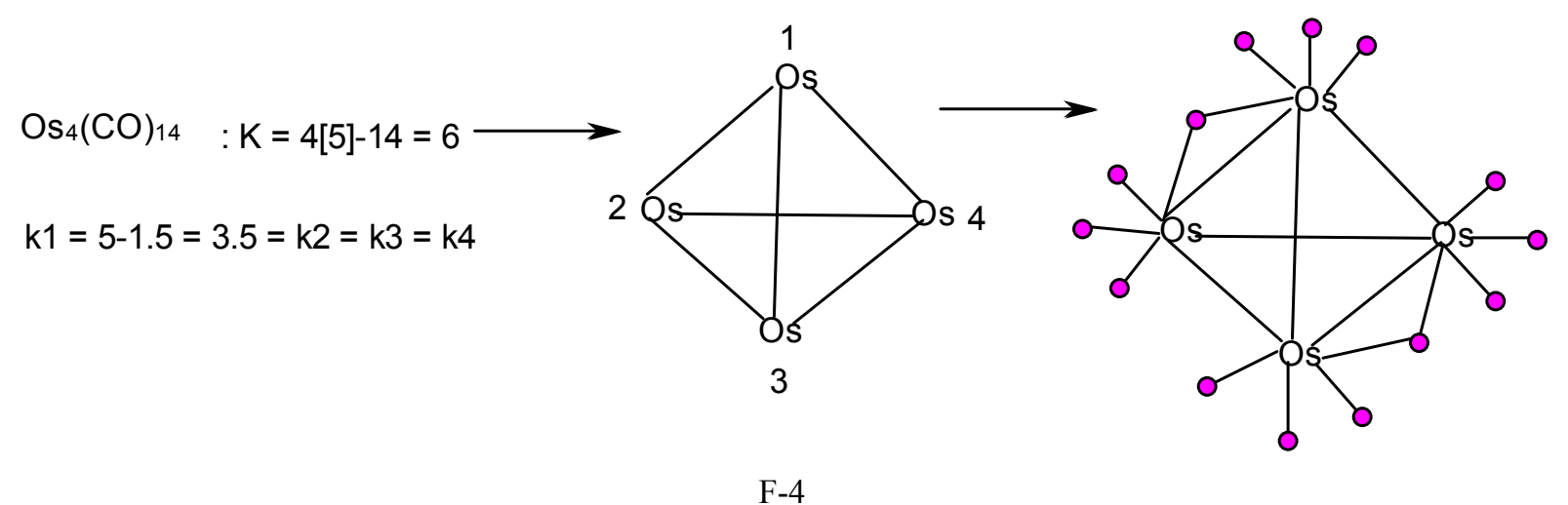

$$
\begin{aligned}
& \mathrm{Os}_{5}(\mathrm{CO}) 18: \mathrm{K}=5[5]-18=7 \\
& \mathrm{k} 1=5-1=4 \\
& \mathrm{k} 2=5-2=3 \\
& \mathrm{k} 3=5-1=4 \\
& \mathrm{k} 4=5-1.5=3.5 \\
& \mathrm{k} 5=\mathrm{k} 4=3.5
\end{aligned}
$$

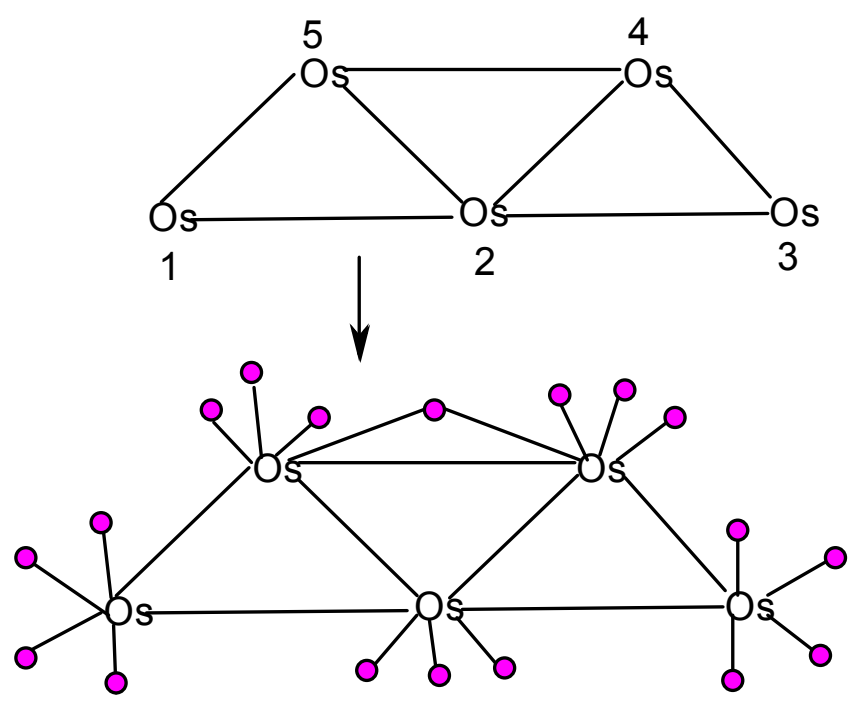

F-5

$$
\begin{aligned}
& \mathrm{k} 1=5-1.5=3.5 \\
& \mathrm{k} 2=5-2=3 \\
& \mathrm{k} 3=5-2=3 \\
& \mathrm{k} 4=5-2=3 \\
& \mathrm{k} 5=5-1.5=3.5
\end{aligned}
$$$$
\mathrm{Os}_{5}(\mathrm{CO}){ }_{16}: \mathrm{K}=5[5]-16=9
$$
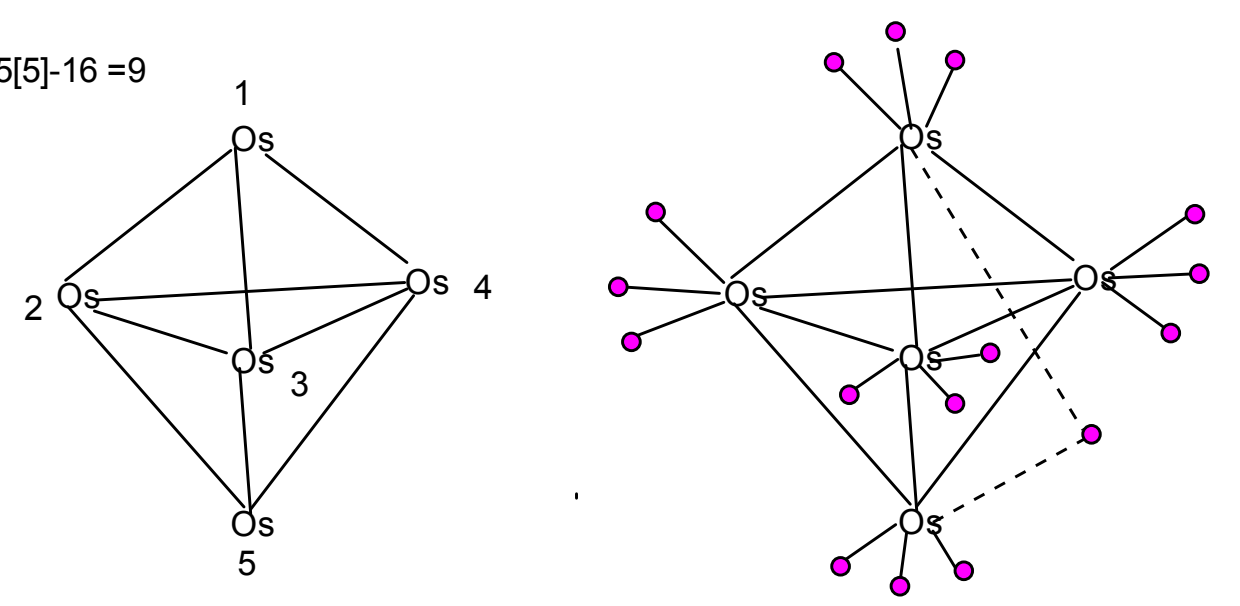

F-6 
$\mathrm{Os}_{6}(\mathrm{CO}) 18^{2-} \quad \mathrm{K}=6[5]-18-1=11$

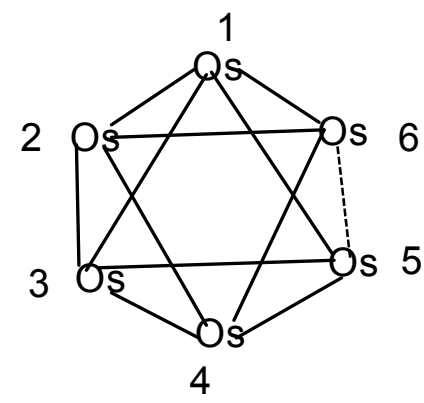

$$
\begin{array}{ll}
\mathrm{k} 1=5-2=3 & \mathrm{k} 4=5-2=3 \\
\mathrm{k} 2=5-2=3 & \mathrm{k} 6=5-1.5=3.5 \\
\mathrm{k} 3=5-2=3 &
\end{array}
$$

F-7

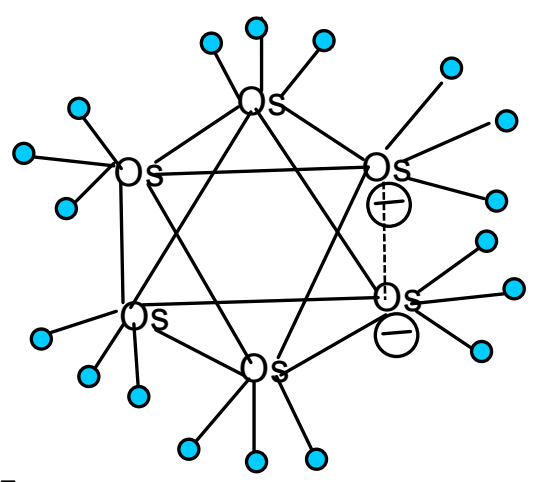

$\mathrm{Re}_{4} \mathrm{H}_{5}(\mathrm{CO}){ }_{14^{-}} \quad ; \mathrm{K}=4[5.5]-2.5-14-0.5=5$
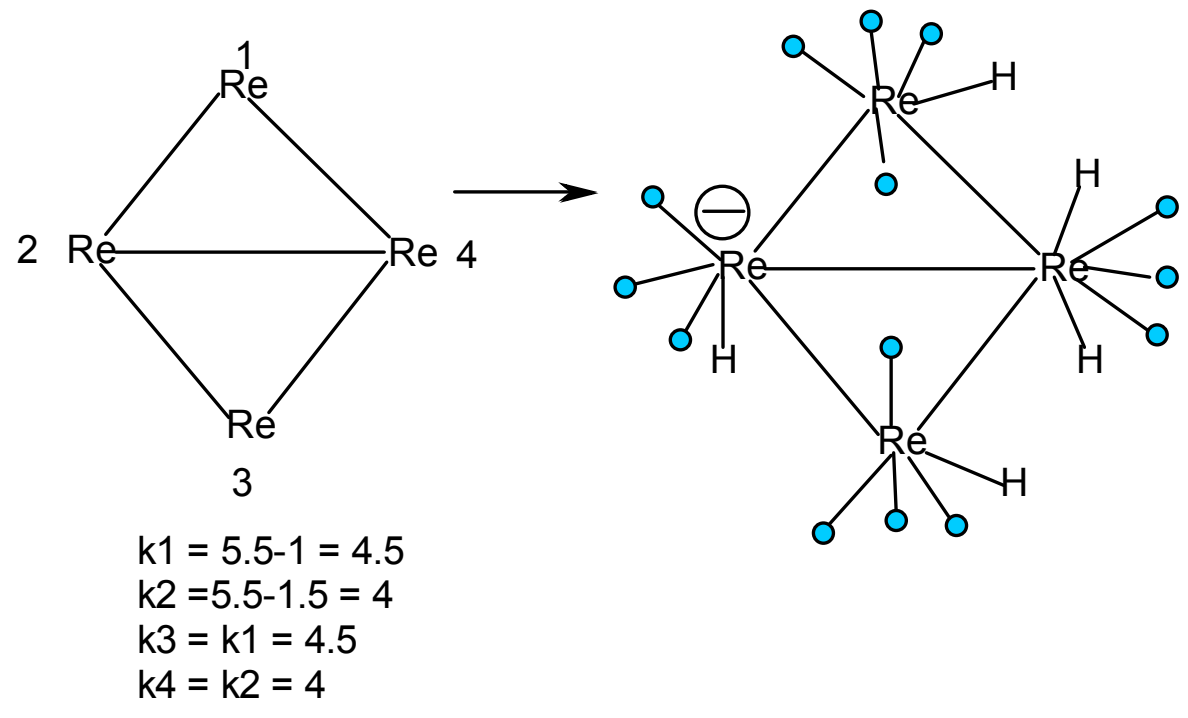

F-8 
$\mathrm{Re}_{6} \mathrm{H}_{5}(\mathrm{CO})_{24^{-}} \quad ; \mathrm{K}=6[5.5]-2.5-24-0.5=6$

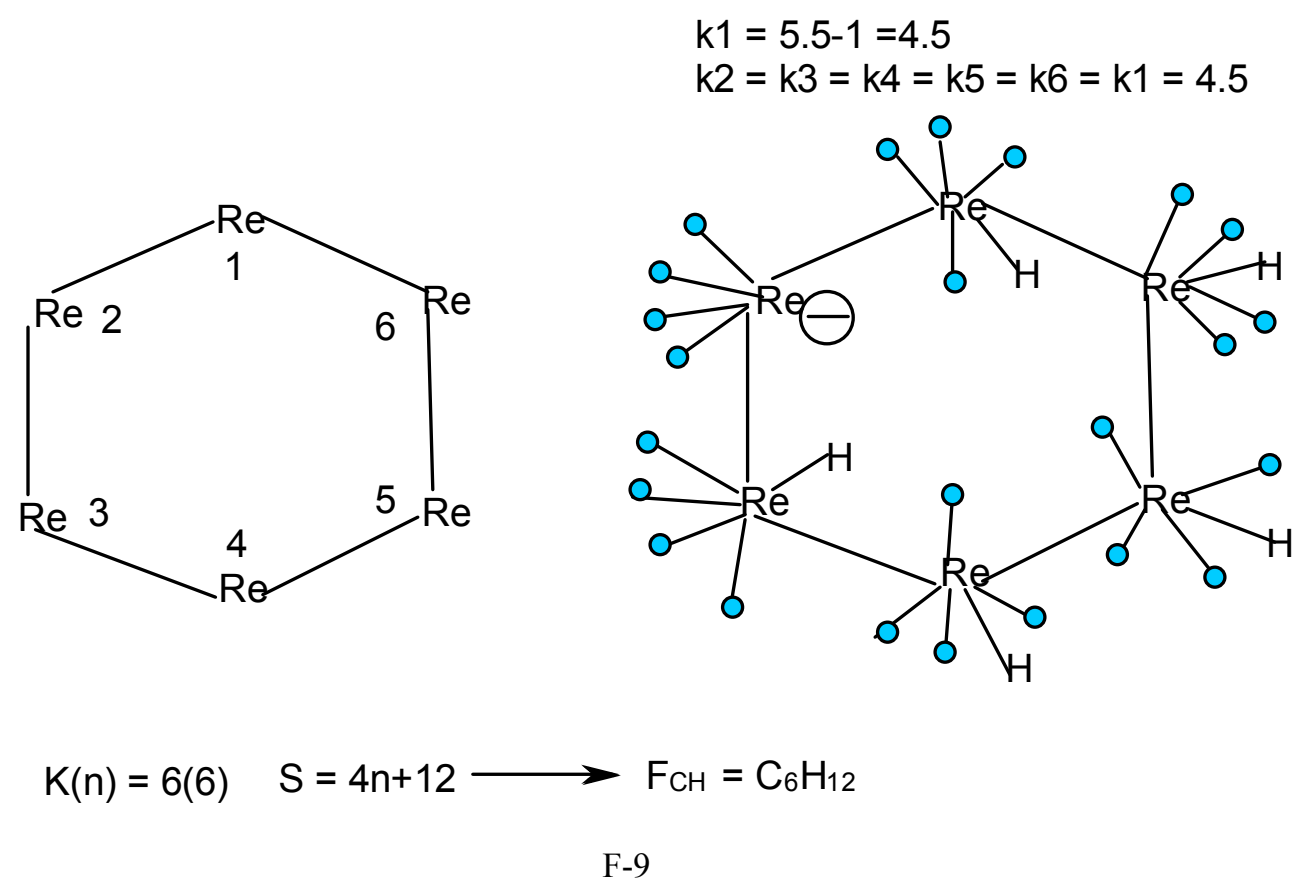

2.8 Using Skeletal Numbers to Test the 18-Electron Rule in Multi-skeletal Clusters

Let us consider a few examples (Meissler, 2014) given below. The details of the method are also explained for each of the sketches (F-1 to F-9 and F-10 to F-12). The $\mathrm{K}$ values were calculated using the appropriate skeletal numbers presented in Tables 1 to 3 .

$\begin{array}{rlr}\text { 1. } \quad \operatorname{Re}_{2}(\mathrm{Cp})_{2}(\mathrm{CO})_{5} \longrightarrow & \begin{array}{l}\mathrm{k} 1 \\ \mathrm{Re} \\ \mathrm{K}=2[5.5]+2[-2.5]+5[-1] \\ =11-5-5=1\end{array} & \mathrm{k} 1=\mathrm{k} 2=1[5.5]+1[-0.5]=5.5-0.5=5 \\ & \end{array}$

If we divide the ligands between the $2 \mathrm{Re}$ skeletal atoms we get, [ $2 \mathrm{Cp}+5 \mathrm{CO}] / 2$ $=1 \mathrm{Cp}+2.5 \mathrm{CO}$.

In terms of $K$ values $=1[-2.5]+2.5[-1]=-5.0$. This clearly means that if we evenly distribule the ligands around the $2 \mathrm{Re}$ skeletal elements, the overall $\mathrm{K}$ value on each rhenium atom will be 0 . In that way, each Re skeletal element wil obey the 18 electron rule. On this basis, the sketch of the complex will be as shown in F-10.

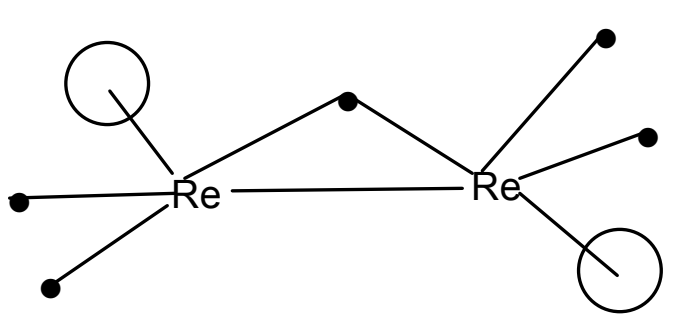

F-10

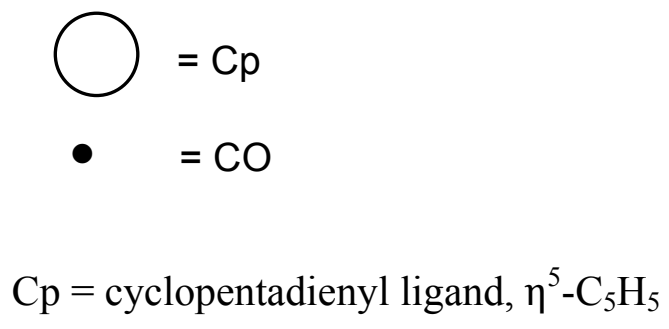

$\mathrm{Cp}=$ cyclopentadienyl ligand, $\eta^{5}-\mathrm{C}_{5} \mathrm{H}_{5}$ 


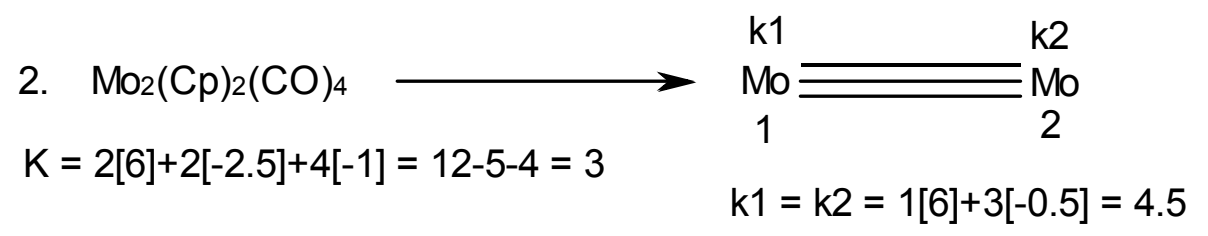

Let us divide the ligands among the $2 \mathrm{Mo}$ skeletal elements we get, $[2 \mathrm{Cp}+4 \mathrm{CO}] / 2=\mathrm{Cp}+2 \mathrm{CO}$.

The $\mathrm{K}$ value of $1 \mathrm{Cp}+2 \mathrm{CO}=1[-2.5]+2[-1]=-4.5$. This means that if we add $1 \mathrm{Cp}$ and $2 \mathrm{CO}$ ligands to each Mo skeletal element the net $\mathrm{K}$ value on the Mo atom will be 0 . This implies the skeletal atom obeys the 18 electron rule. A sketch of the complex is given in F-11.

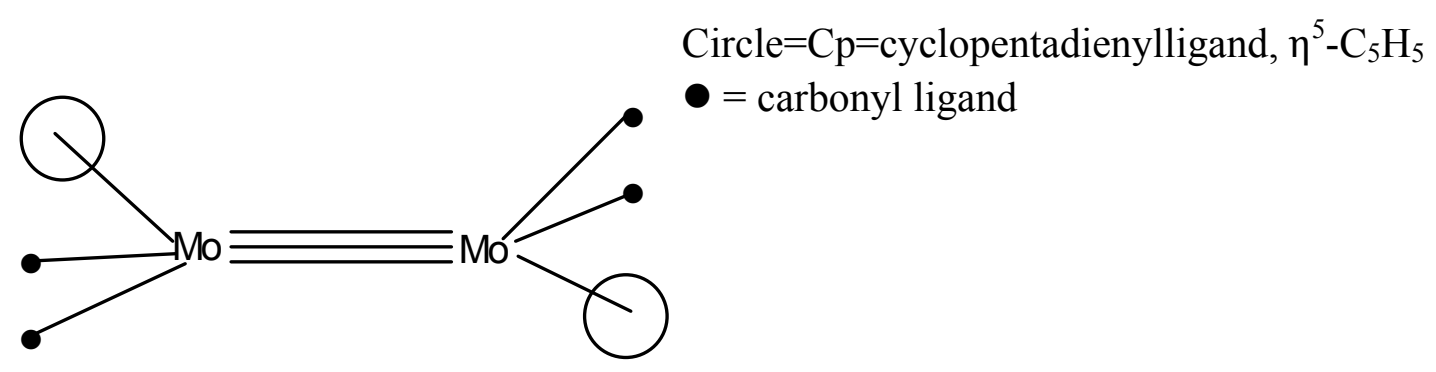

F-11

3. $\operatorname{Ir}_{4}(\mathrm{CO}) 12$

The $\mathrm{K}$ value is given by $\mathrm{K}=4[4.5]+12[-1]=18-12=6$. The skeletal sketch is given in $\mathrm{F}-12$.

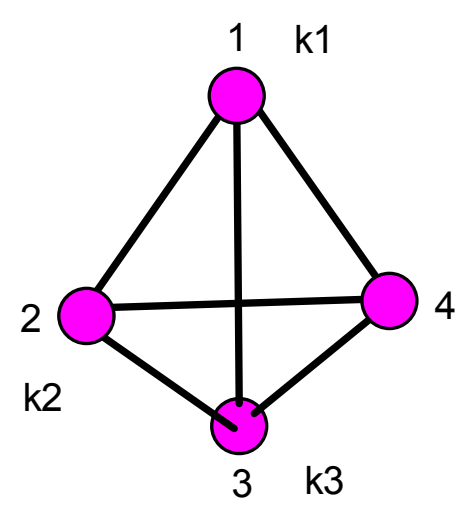

$\mathrm{k} 1=\mathrm{k} 2=\mathrm{k} 3=\mathrm{k} 4=1[4.5]+3[-0.5]=3$.

If we divide the ligands among the 4 skeletal elements we get $3 \mathrm{CO}$.

The $\mathrm{K}$ value of $3 \mathrm{CO}=3[-1]=-3$. This means that adding $3 \mathrm{CO}$ ligands to each skeletal element the net $\mathrm{K}$ value of the skeletal atom $=0$. Ideally, this means that the skeletal atom obeys the 18 electron rule. The sketch of the cluster is given in F-12.

\section{F-12}

\section{Conclusion}

The various areas in which skeletal numbers can be utilized in categorizing fragments and clusters have been presented. These include predicting whether a cluster obeys the 8 or 18 electron rule, categorization of a given cluster and predicting its possible geometry, the linkage of the cluster number $\mathrm{K}(\mathrm{n})$ with a possible specific geometry, and the 
matching of fragments which are isolobal. More importantly, the skeletal numbers can be used as a guide to distribute ligands to skeletal geometries of clusters in order to generate possible cluster isomers. The method has been found to be easy and rapid in categorizing a cluster into its series and generally precise in predicting the geometrical shape of a cluster.

\section{Acknowledgement}

The University of Namibia is greatly acknowledged for providing the enabling environment and facilities to support this work and Dr. P. E. T. Kiremire and Mrs M.K. Kiremire for proof-reading the draft.

\section{References}

Ciabatti, I. (2015). Homo-and Heterometal carbonyl Nanoclusters. PhD Thesis. Universita Di Bologna.

Cotton, F. A., \& Wilkinson, G. (1980). Advanced Inorganic Chemistry, $4^{\text {th }}$ Ed., John Wiley and Sons, New York, 1980.

de Sausa, D. W. O., \& Nascimanto, M. A. C. (2016). Is There a Quadruple Bond in $\mathrm{C}_{2}$ ? J. Chem. Theory Comput., 12(5), 2234-2241. https://doi.org/10.1021/acs.jctc.6b00055

Greenwood, N. N., \& Earnshaw, A. (1998). Chemistry of the Elements, $2^{\text {nd }}$ Ed.,Butterworth, Oxford.

Hoffmann, R. (1982). Building Bridges Between Inorganic and Organic Chemistry. Angew. Chem. Int. Ed. Engl., 21, 711-724. https://doi.org/10.1002/anie.198207113

Housecroft, C. E., \& Sharpe, A. G. (2005). Inorganic Chemistry, $2^{\text {nd }}$ Ed., Pearson, Prentice Hall, Harlow, England

King, R. B., \& Schleyer, P. V. R. (2004). Molecular Clusters of the Main Group Elements, Edited by M. Driess and H. NÖ̈th, Wiley-VCH: Heppenheim, Germany.

Kiremire, E. M. (2014). Validation and verification of the Expanded Table for Transition Metal Carbonyl and Main Group Element Cluster Series which obey the 18-Electron and the 8-Electron Rules Respectively. Orient. J. Chem., 30(4), 1475-1495. https://doi.org/10.13005/ojc/300404

Kiremire, E. M. (2015a). Classification of Transition Metal Carbonyl Clusters Using the 14n Rule Derived from Number Theory. Orient. J. Chem., 31(2), 605-618. https://doi.org/10.13005/ojc/310201

Kiremire, E. M. (2015b). Categorization and Structural Determination of Simple and More Complex Carbonyl Clusters of Rhenium and Osmium Using $\mathrm{k}$ values and the Cluster Table. Orient. J. Chem., 31(1), 293-302. https://doi.org/10.13005/ojc/310133

Kiremire, E. M. (2015c). Isolobal Series of Chemical Fragments. Orient. J. Chem. ,31(spl. Edn), 59-70.

Kiremire, E. M. (2015d). A Unique Bypass to the Carbonyl Cluster Nucleus Using the 4n Series. Orient. J. Chem., 31(3), 1469-1476. https://doi.org/10.13005/ojc/310326

Kiremire, E. M. R. (2016b). Clusters of Gold containing p-Block Elements. Am. J. Chem., 6(5), 126-144.

Kiremire, E. M. R. (2016c). The Application of the 4n Series Method to Categorize Metalloboranes. Int. J. Chem., 8(3), 62-73. https://doi.org/10.5539/ijc.v8n3p62

Kiremire, E. M. R. (2016d). Classification of Zintl Ion Clusters Using 4n Series Approach. Orient. J. Chem., 32(4), 1731-1738. https://doi.org/10.13005/ojc/320401

Kiremire, E. M. R. (2017). The Golden Series and Clusters of Gold-unique Shapes and Bonding. Int. J. Chem., 9(1), 38-57. https://doi.org/10.5539/ijc.v9n1p38

Langmuir, I. (1921). Types of Valence. Science, 54, 59-67. https://doi.org/10.1126/science.54.1386.59

Lewis, G. N. (1916). The Atom and the Molecules. J. Am. Chem. Soc., 38(4), 762-785. https://doi.org/10.1021/ja02261a002

Miessler, G., Fischer, P., \& Tarr, D. (2014). Inorganic Chemistry, $5^{\text {th }}$ Edition, Pearson Education, Inc., Upper Saddle River

Mingos, D. M. P. (1972). A General Theory for Cluster and Ring Compounds of the Main Group and Transition Elements. Nature (London), Phys. Sci., 236, 99-102. https://doi.org/10.1038/physci236099a0

Rudolph, R. W. (1976). Boranes and heteroboranes: a paradigm for the electron requirements of clusters? Acc. Chem. Res., 9(12), 446-452. https://doi.org/10.1021/ar50108a004

Shaik, S., Danovich, D., Wu, W., Su, P., Rzepa, H. S., \& Hiberty, P. C. (2012). Quadruple bonding in $\mathrm{C}_{2}$ and analogous eight valence electron species. Nature Chemistry, 4, 195-200. https://doi.org/10.1038/nchem.1263

Teo, B. K., Longoni, G., \& Chung, F. R. K.(1984). Applications of Topological Electron-Counting Theory to Polyhedral 
Metal Clusters. Inorg. Chem., 23(9), 1257. https://doi.org/10.1021/ic00177a018

Wade, K. (1971). The structural significance of the number of skeletal bonding electron-pairs in carboranes, the higher boranes and borane ions and various transition metal carbonyl cluster compounds. Chem. Commun., 792-793. https://doi.org/10.1039/c29710000792

Welch, A. J. (2013). The significance of Wade's rules. Chem. Commun., 49, 3615-3616. https://doi.org/10.1039/c3cc00069a

\section{Copyrights}

Copyright for this article is retained by the author(s), with first publication rights granted to the journal.

This is an open-access article distributed under the terms and conditions of the Creative Commons Attribution license (http://creativecommons.org/licenses/by/4.0/). 